\title{
الاختيار المهني وعلاقته بالمرونة النفسية لاى طلاب الصف العاثر بمحافظة غرب خان يونس بالمرنة - فلسطين
}

\author{
محمد منذر يوسف عبد الخالق دحلان \\ غزة ـ فلسطين \\ البريد الاككتروني: mdahalan1a@gmail.com
}

الملخص

هدفت هذه الدراسة للكثف عن مستوى الاختيار المهني و علاقته بالمرونـة النفسية لدى طلاب الصف العانشر بمحافظة غرب خان يونس، بقطاع غزة. ولقد تم تطبيق أدوات الدر اسـة المتمثلة في مقاييس: الاختيار المهني، المرونـة النفسية، مـن إعداد الباحث على عينـة الدراسـة المكونـة مـن (240) مـن طـلاب الصف العانشر للعـام (2021، 2022)، اتبع الباحث المنهج الوصفي، وقد أظهرت النتائج وجود مستوى مرتفع لكل من الاختيار المهني و المرونة النفسية، وجود علاقة ذات دلالة إحصائية بين الاختبار المهني و المرونة النفسية، وعدم جود فروق ذات دلالة إحصائية لاى عينة الدر اسة في مستوى كل من الاختيار المهني، و المرونـة النفسية، تبعُا للنوع. و عدم جود

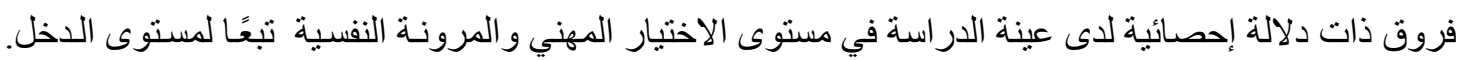
وجود فروق ذات دلالـة إحصـائية لدى أفر اد العينـة في مستوى كل من الاختيـار المهني و المرونـة النفسية تبعًا لمتغير مستوى التحصيل، وتوجد فروق ذات دلالة إحصـائيًا للدى أفر اد العينة في مستوى الاختبار المهني تبعًا لمتغير اختيار التخصص لصالح الفئة (علمي)، لا توجد فروق ذات دلالة إحصـائية في مستوى المرونـة النفسية تبعًا لمتغير اختيار التخصص. الكلمات المفتاحية: الاختيار المهني، المرونة النفسية، طلبة الصف العاشر. 


\title{
Professional Selection and its Relationship to Psychological Resilience among Tenth Graders in West Khan Yunis Governorate - Palestine
}

\author{
Mohammed Monther Y.A. Dahlan \\ Gaza - Palestine \\ Email: mdahalan1a@gmail.com
}

\begin{abstract}
This study aimed to reveal the level of appropriate professional selection and its relationship to psychological resilience among tenth graders in West Khan Yunis Governorate, Gaza Strip. The study tools represented in the scales of professional choice, psychological flexibility prepared by the researcher, were applied to the study sample consisting of (240) tenth grade students for the school year $(2020,2021)$, The researcher followed the descriptive approach and program to analyze the study data. The results concluded the following.:

There is a high level of appropriate professional selection, psychological flexibility , and there is a statistically significant relationship between professional choice and psychological flexibility. Additionally, there are statistically significant differences among the study sample in the level of appropriate professional selection, psychological flexibility, attributable to gender. Also, there are statistically significant differences among the study sample in the level of professional selection and psychological flexibility ascribable to the income level. There are statistically significant differences among the subjects in the level of appropriate professional selection level attributed to the variable of achievement level in favor. There are statistically significant differences among the sample members in the level of appropriate professional selection attributable to the variable of selection of majority in favor of the scientific stream. There are no statistically significant differences in the level of psychological resilience due to the variable of selection a major.
\end{abstract}

Keywords: professional selection, psychological resilience, among tenth graders. 


\begin{tabular}{|c|c|c|c|}
\hline 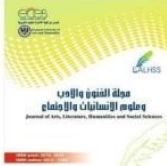 & 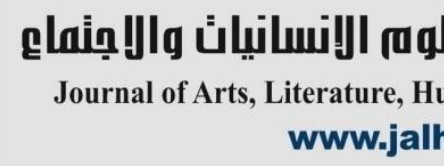 & 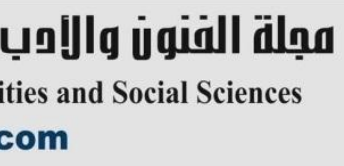 & \\
\hline$=$ & Volume (75) January 2022 & العدد ( 75) يناير 2022 & \\
\hline
\end{tabular}

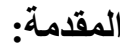

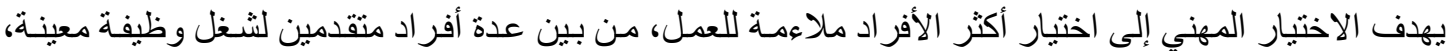

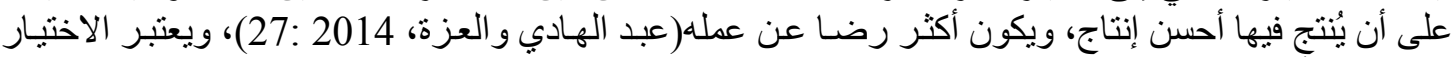

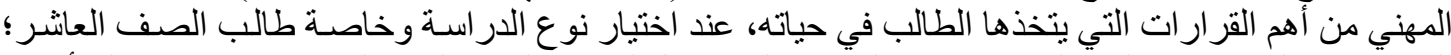

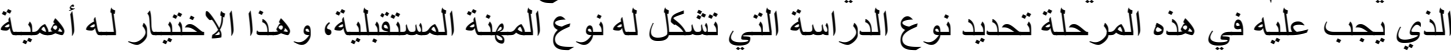

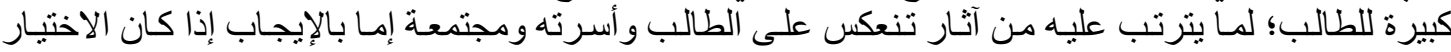

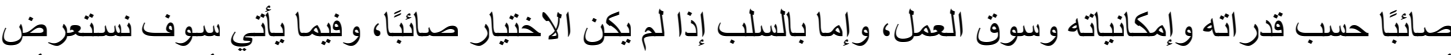

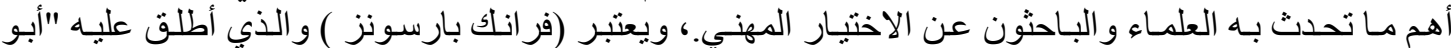

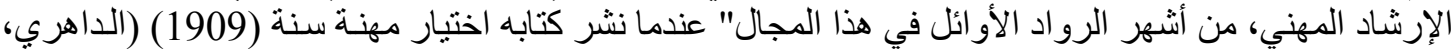

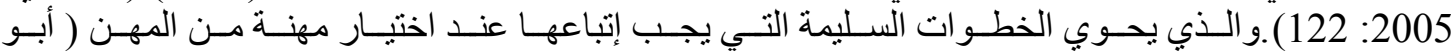

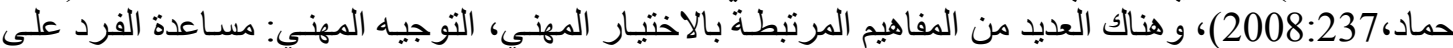

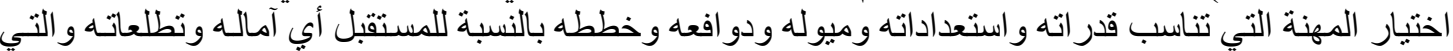

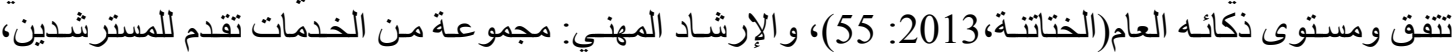

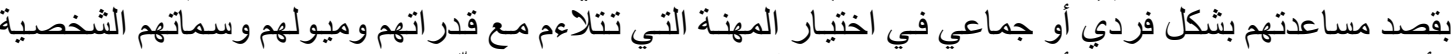

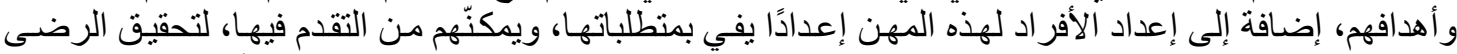

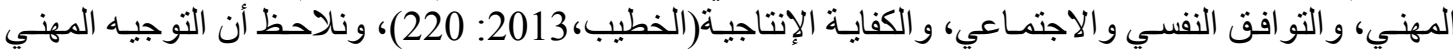

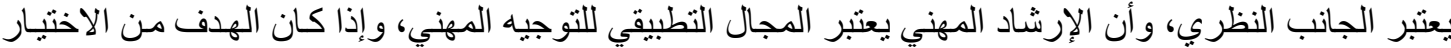

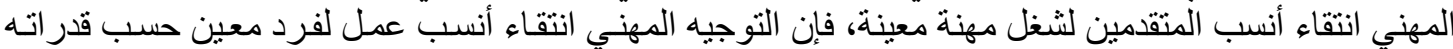

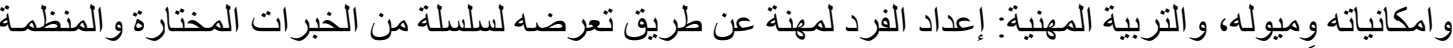

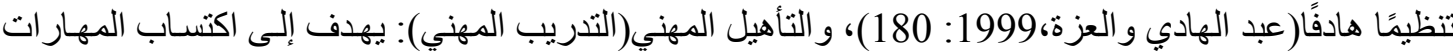

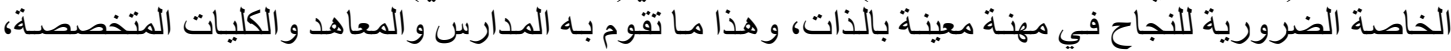

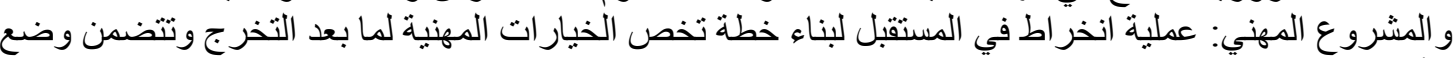

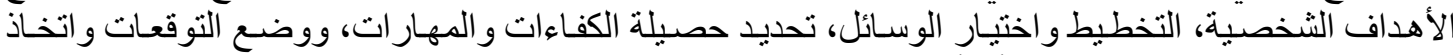

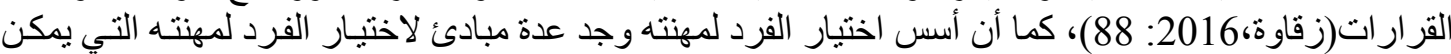

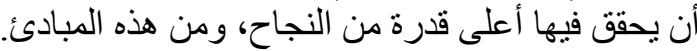

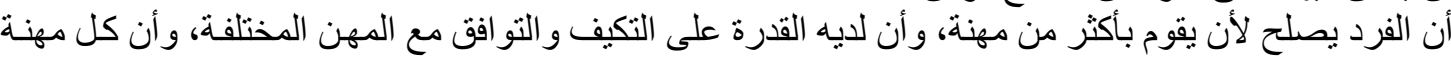

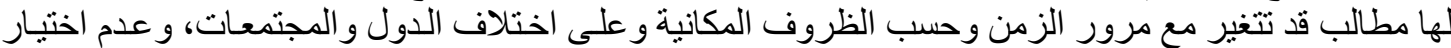

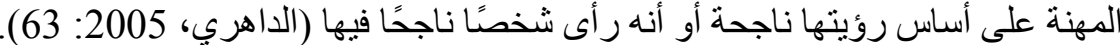
وتكمن أهداف الاختيار المهني في أن الاختيار المهني لا يقتصر على انتقاء أكفأ الأفر اد لمهنـة معينـة بل يهدف الاختيار المهني إلي الافي

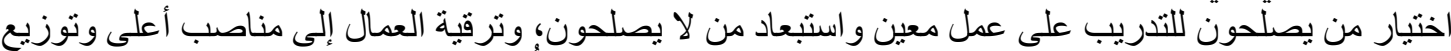

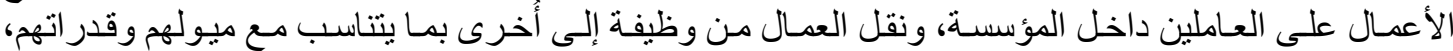

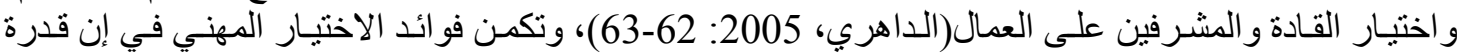

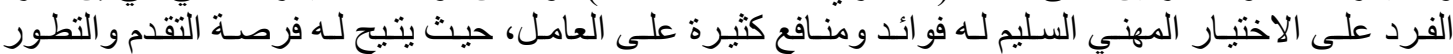

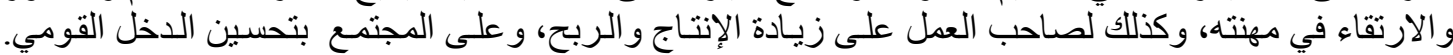

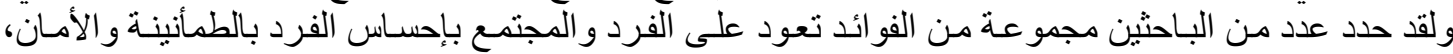

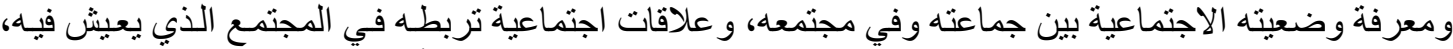

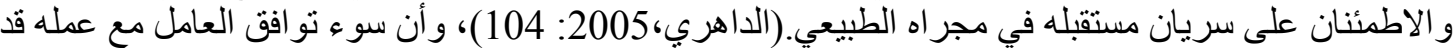

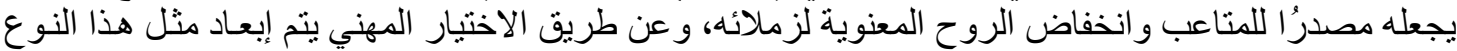

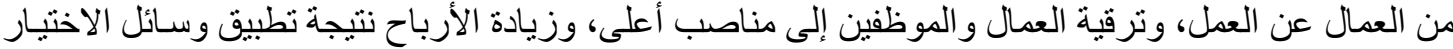

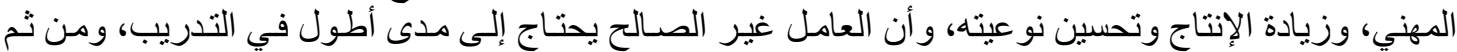

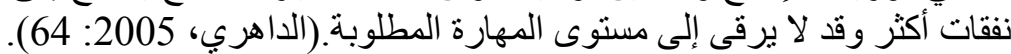

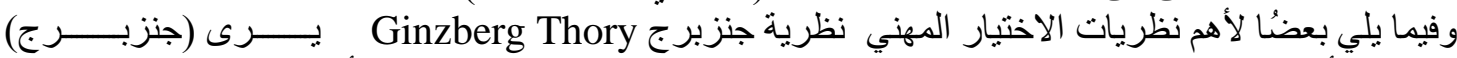
وزملاؤه أن عملية اختيار المهنة عملية نمائية، تسير في اتجاه واحد لا رجعة فيه، كما أنها تنمو وفق فتر ات زمنيـة 


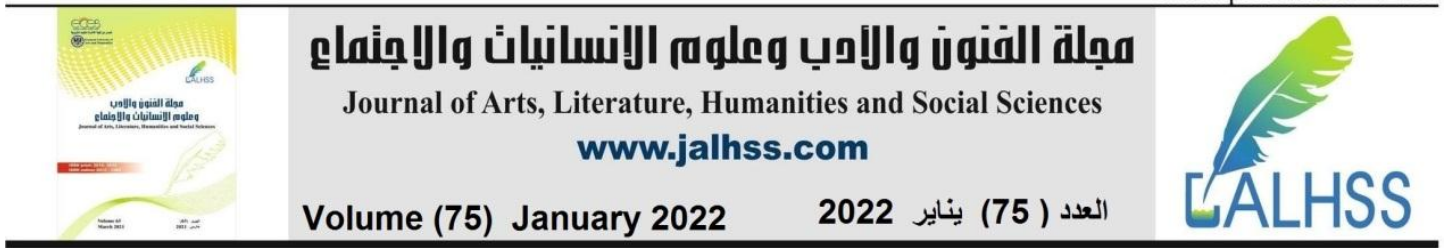



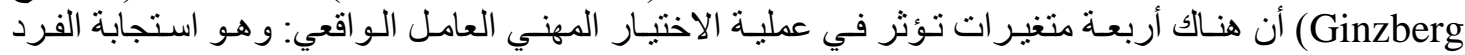

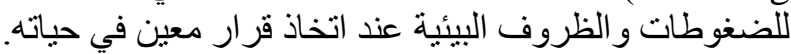

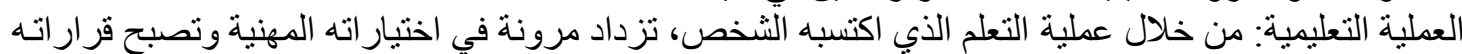

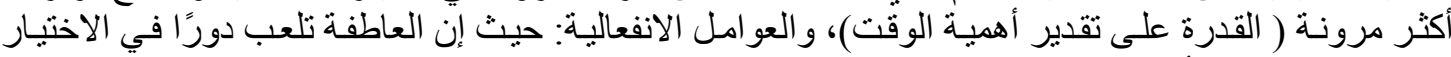

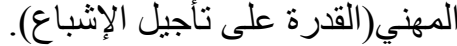

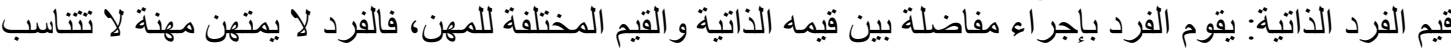

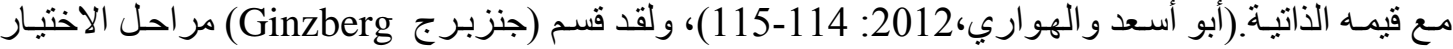

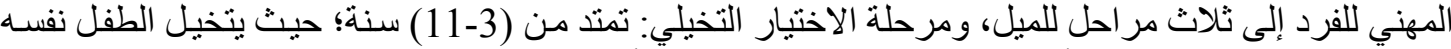

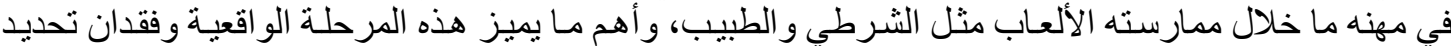

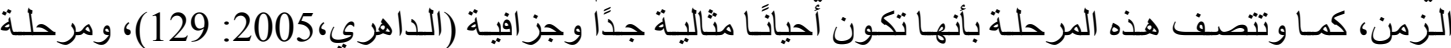

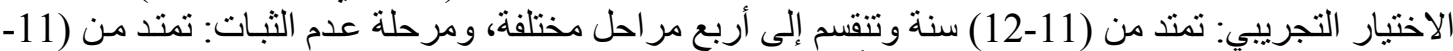

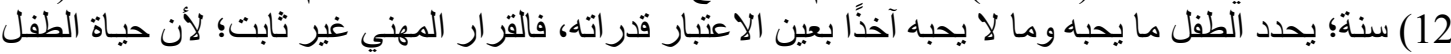

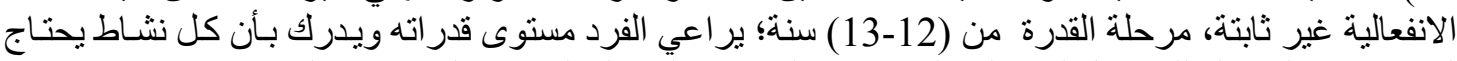

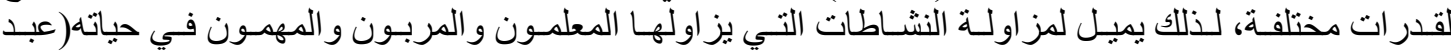

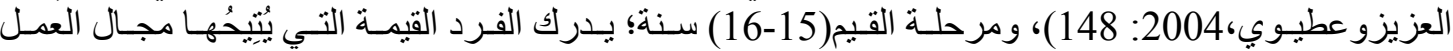

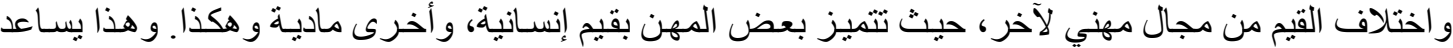

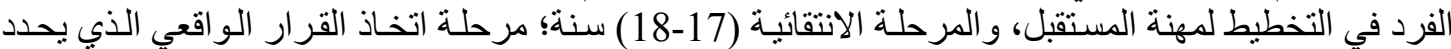

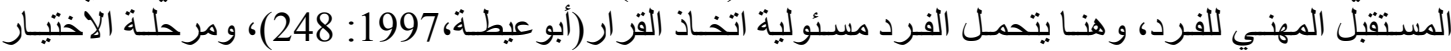

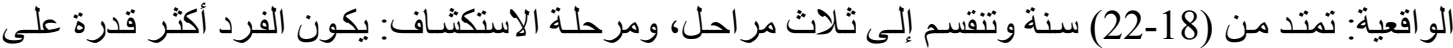

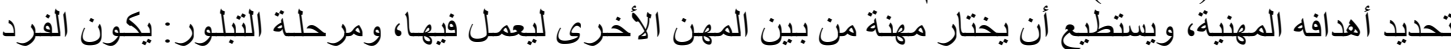

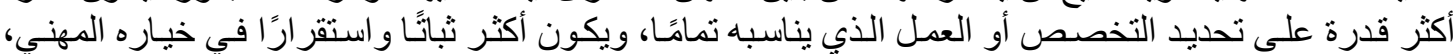

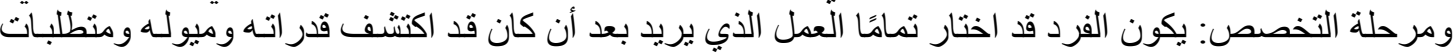

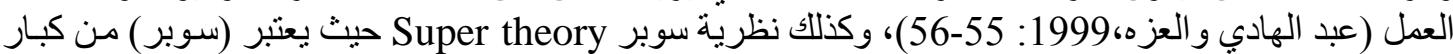
علماء النفس المهني و القياسي، حيث نشر نظريته في النمو المهني (vocational development) عام التير 1953

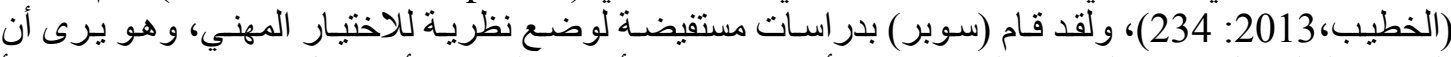

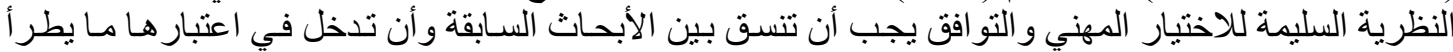

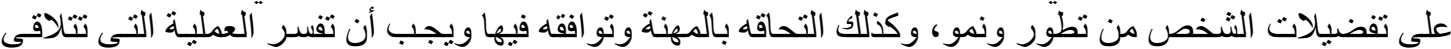

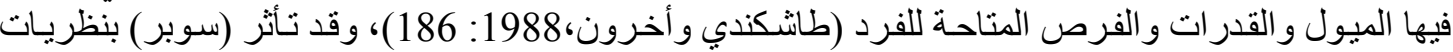

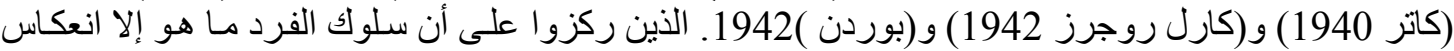

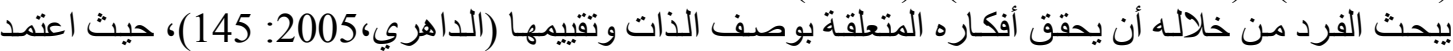

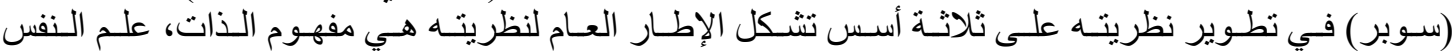

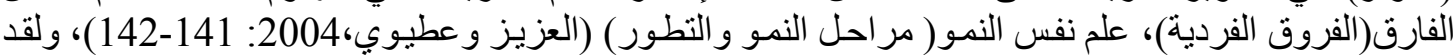

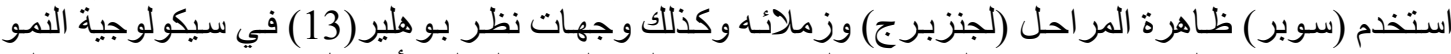

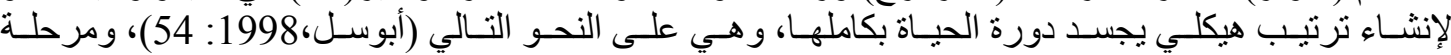

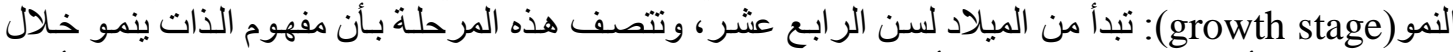

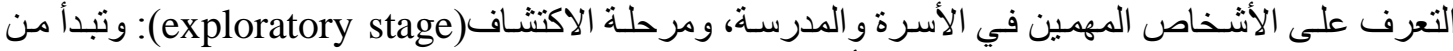

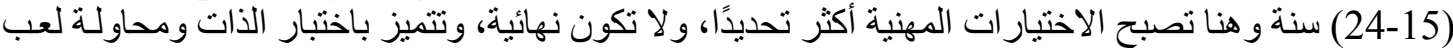

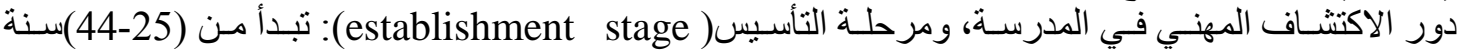

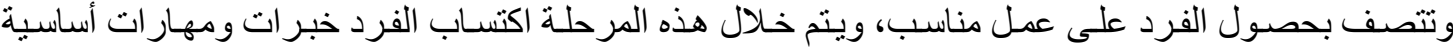

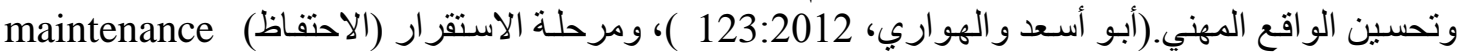

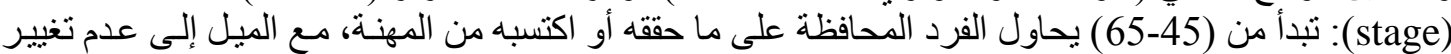

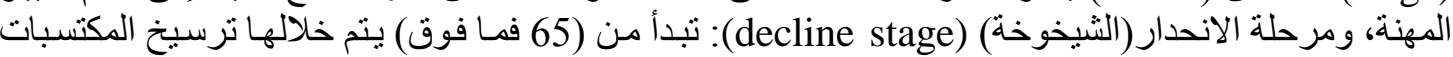

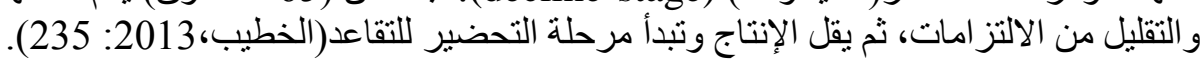




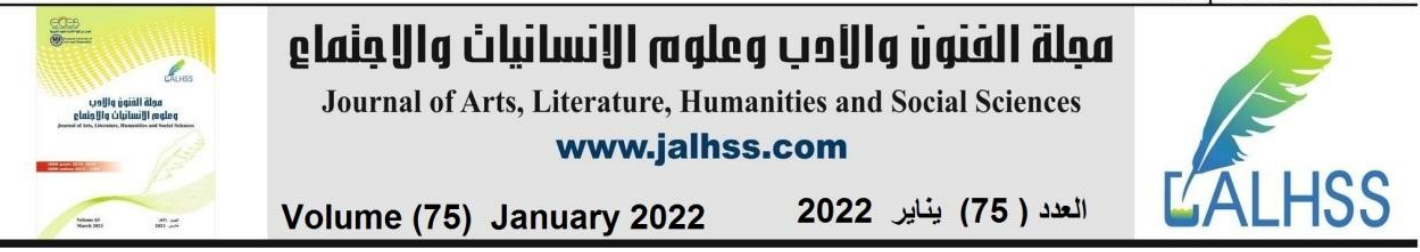

كما وتثكل المرونة النفسية أهمية كبيرة للطلبة؛ لما لها من دور كبير في إدر الك الطلبة لقدر اتهم الذاتية، وتوظيفها

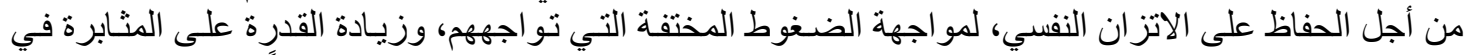

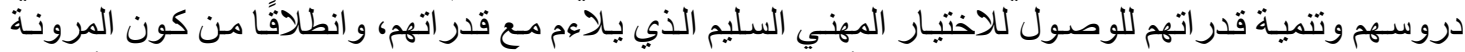

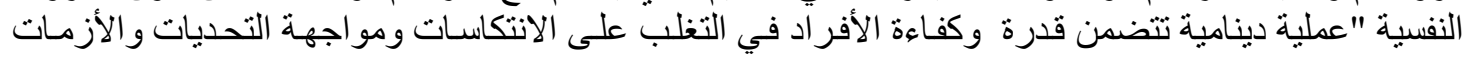

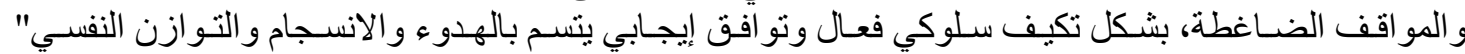

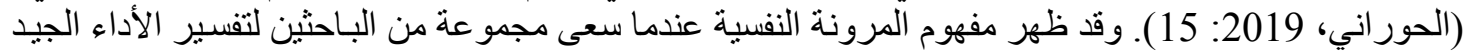

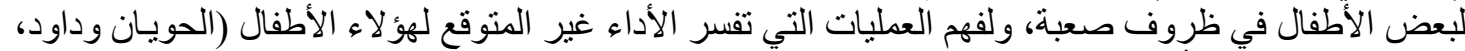

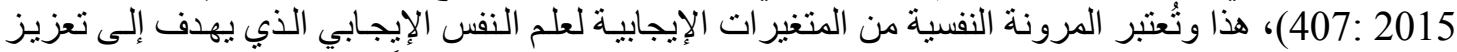

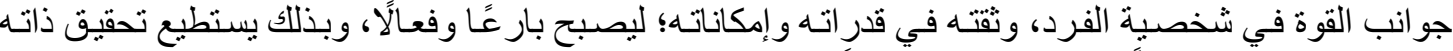

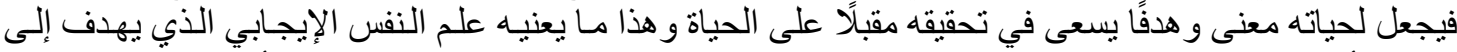

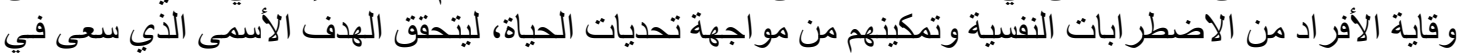
نشره وهو تحسين جودة الحياة وخروج الفرد في حدود التغيير الذاتي إلى إحداث تغيير إيجابي في المجتمع المحيط التيط

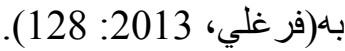

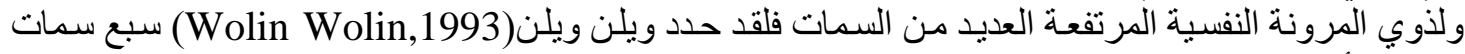

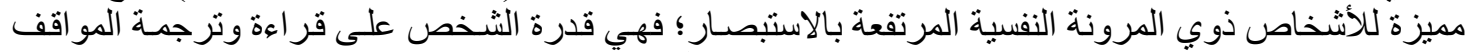

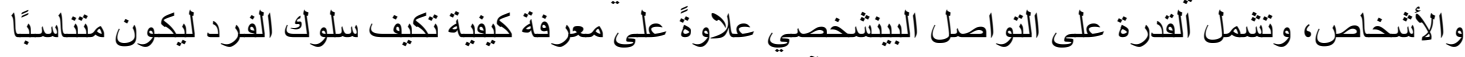

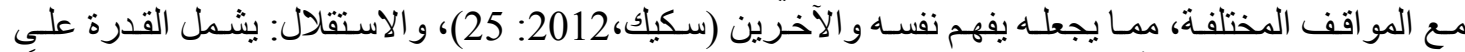

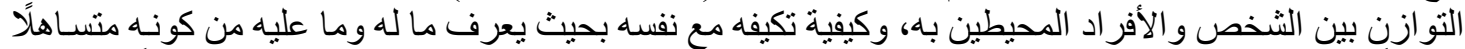

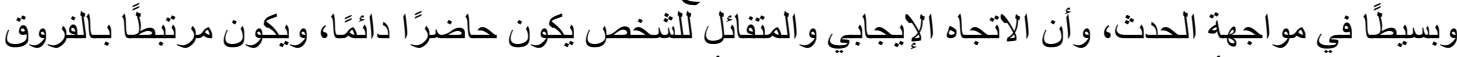

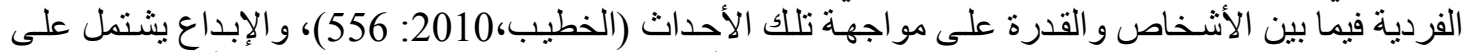

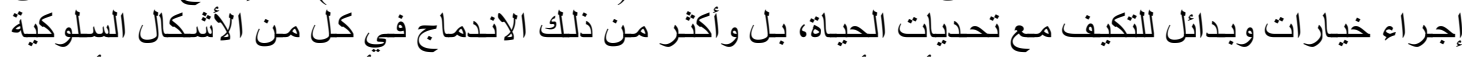

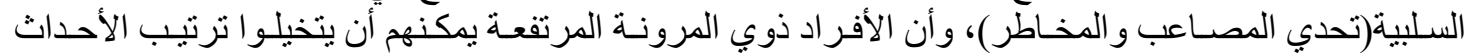

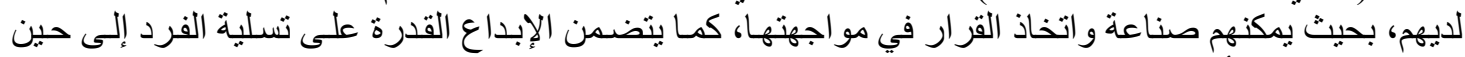

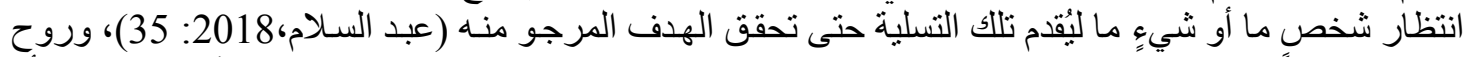

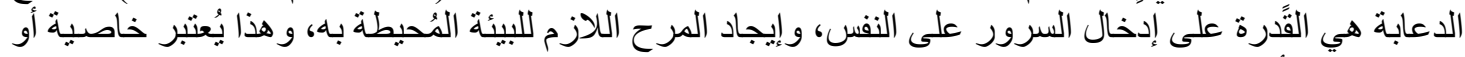

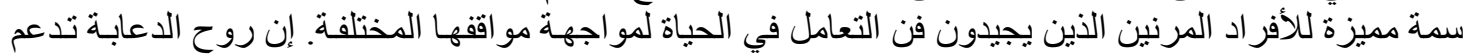

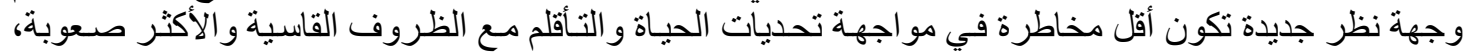

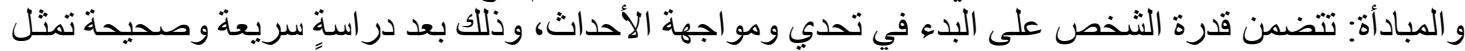

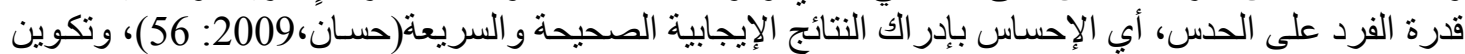

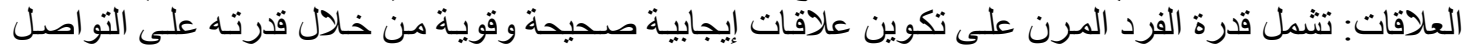

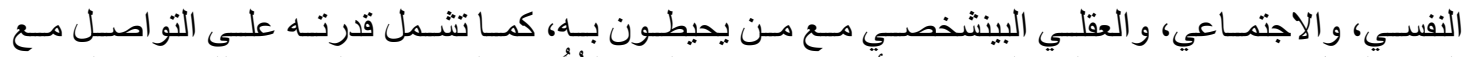

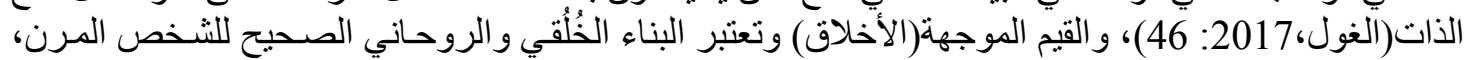

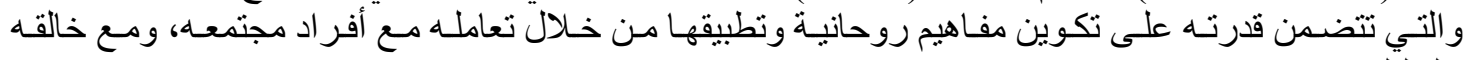

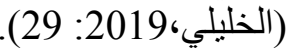

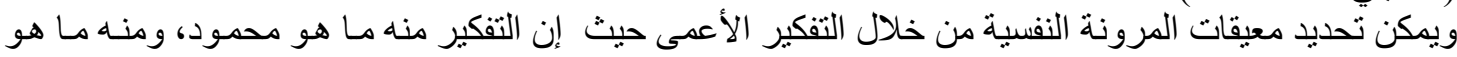

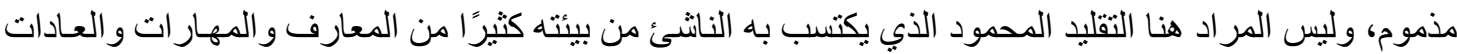

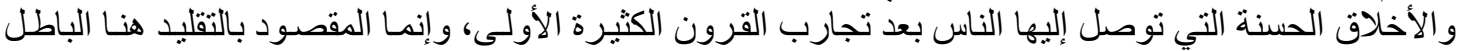

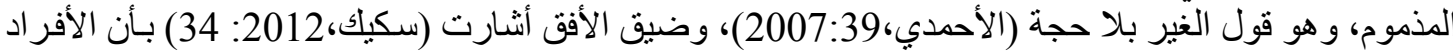

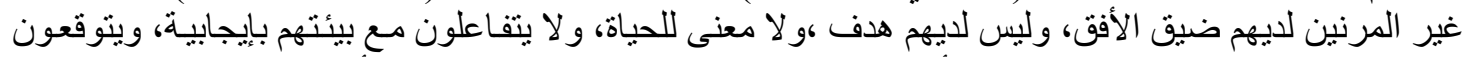

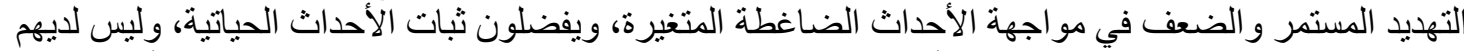

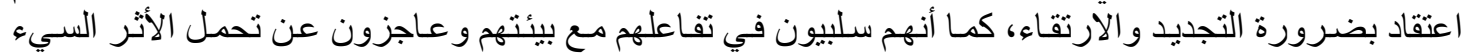

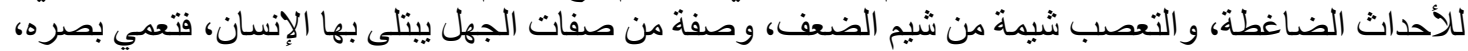

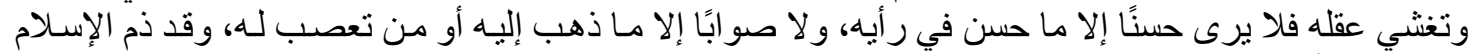
التعصب (الأحمدي، فنديري 2007: 39). 


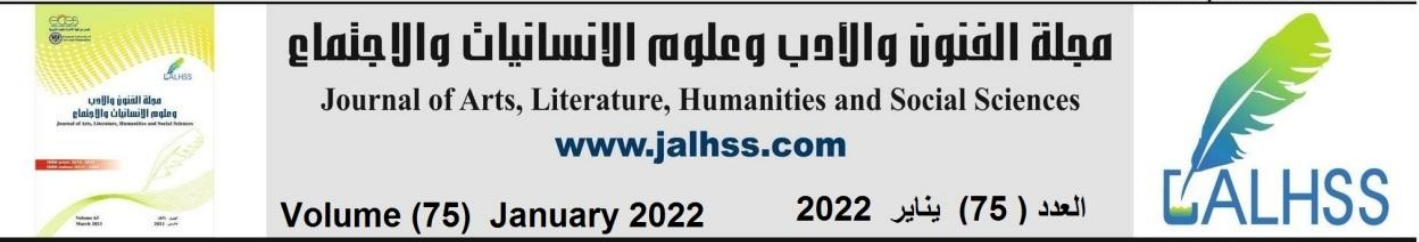

لقد أوضح (الخطيب،2010: 552-553)، أن الإسهامات التجريبيـة في مجال البحث أظهرت ألفرت أن من العو امل

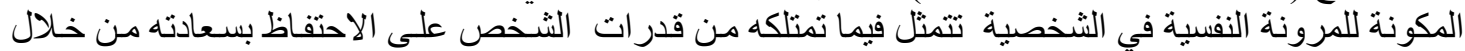

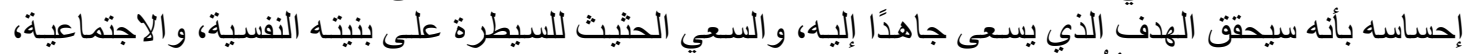

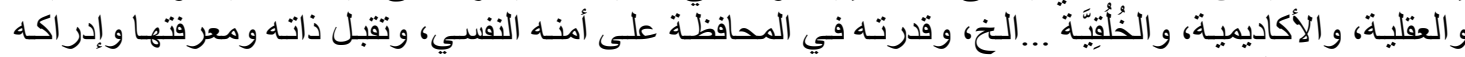

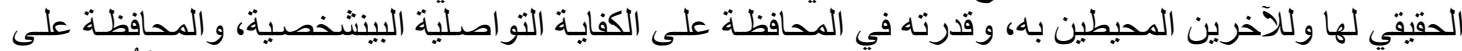

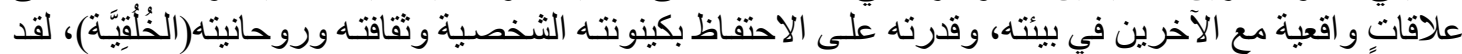

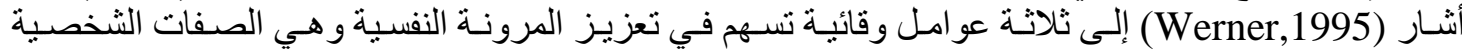

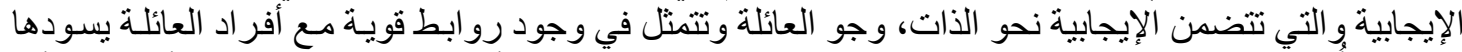

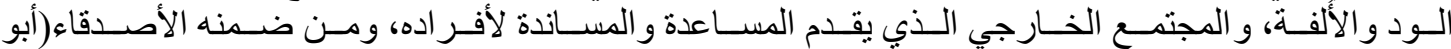

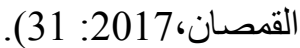

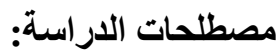

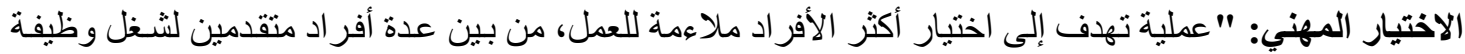

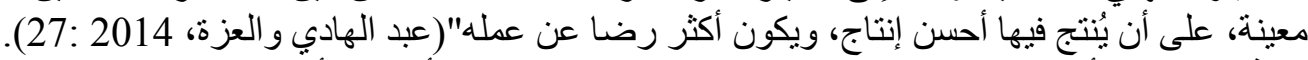

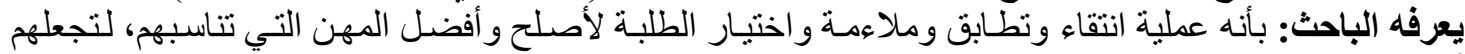

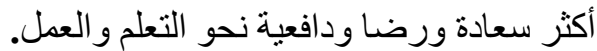

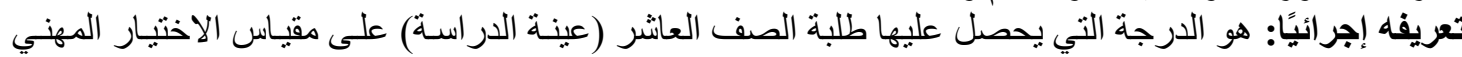
المُعد خصيصًا للار استة الحالية.

Dowrick \& et "المرونـة النفسية: " إنها القدرة على التكيف بنجاح و إحداث التغير ات لمو اجهة التحديات (al,2008: 439)

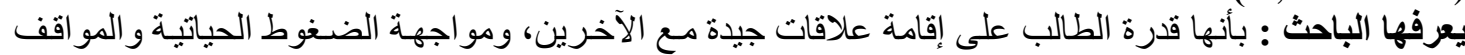

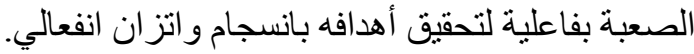

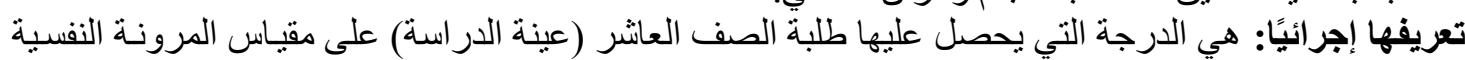

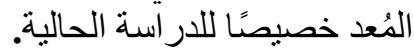

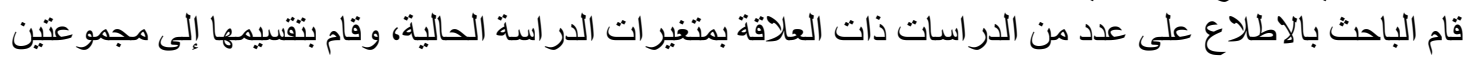

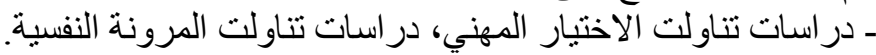

$$
\text { أولاً: الاراسات التي تناولت الاختيار المهني: }
$$

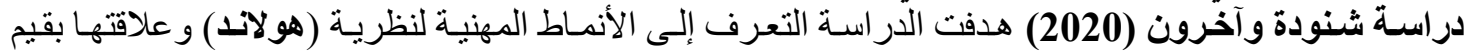

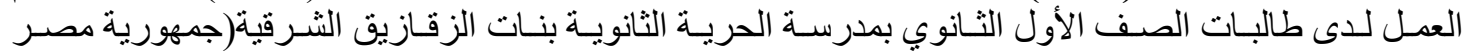

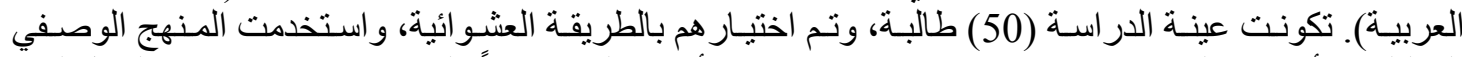

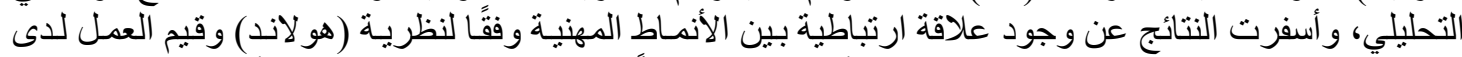

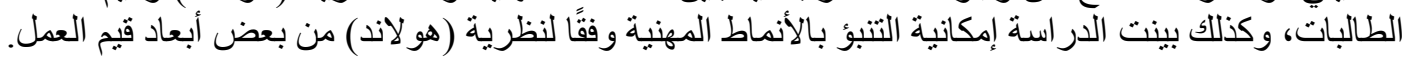

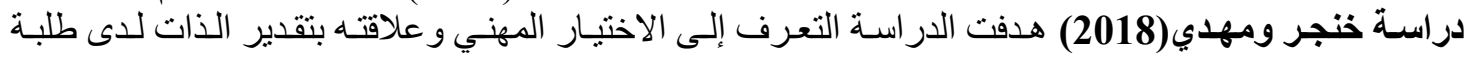

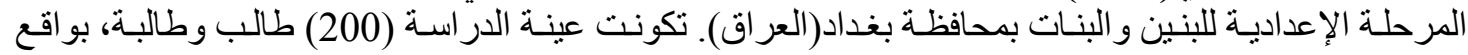

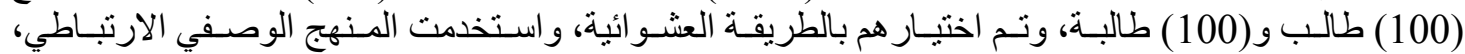

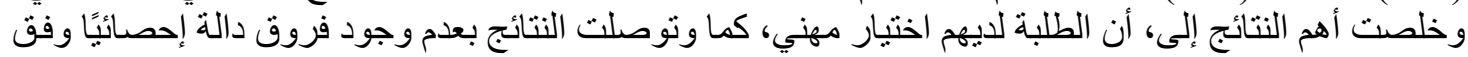

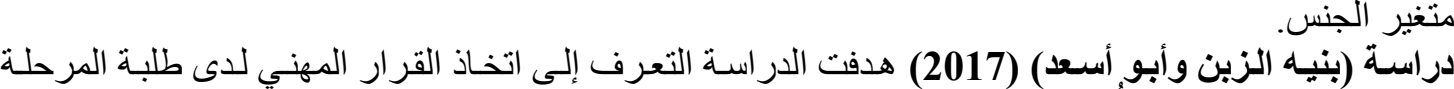

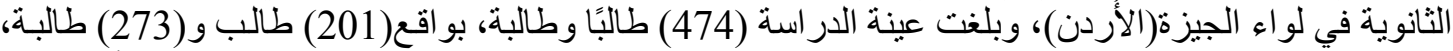

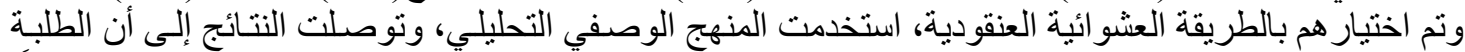

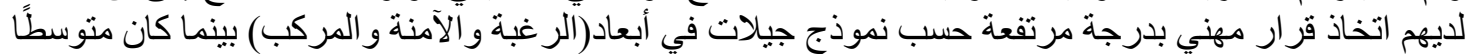

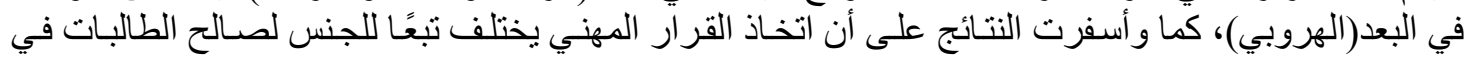




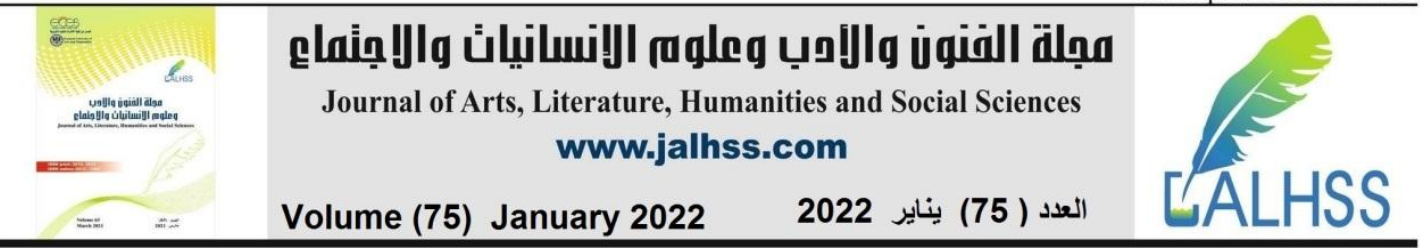

أبعاد(الرغبة و المركب و الدرجة الكلية)، كما وبينت أن اتخاذ القرار المهني يعد أفضل لدى الطلبة ذوي التخصص العلمي من ذوي التخصص العرك الأدبي.

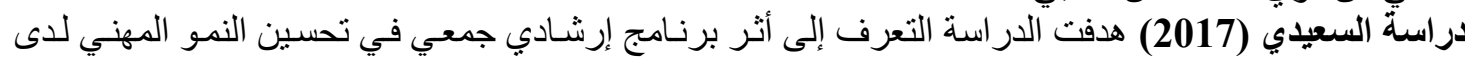

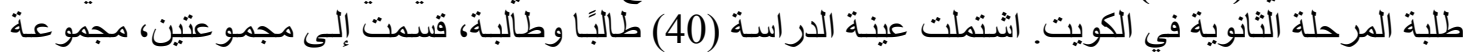

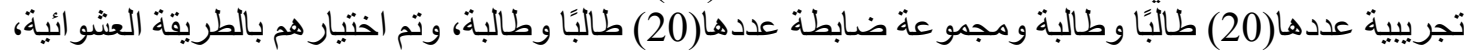

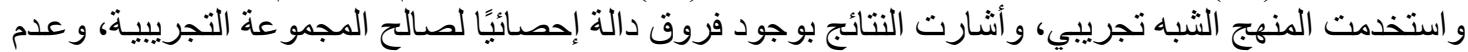

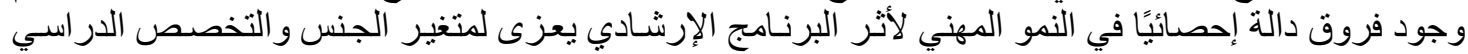

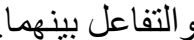

دراسة صباح وبركات (2017) هدفت التعرف إلى تقنين قائمة التفضيل المهني (لهولاند) على البيئة الفلسطينية.

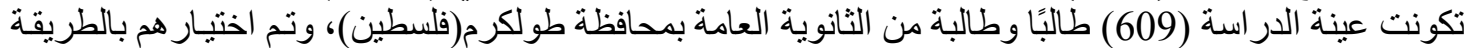

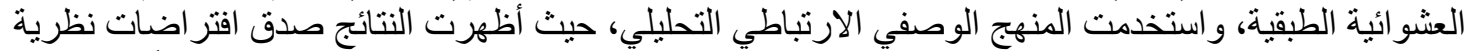

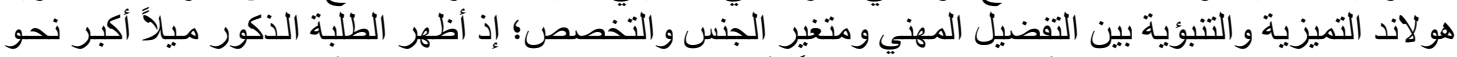

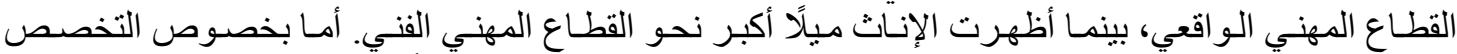

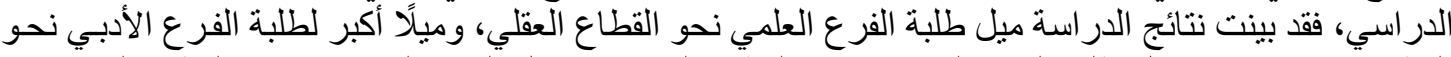

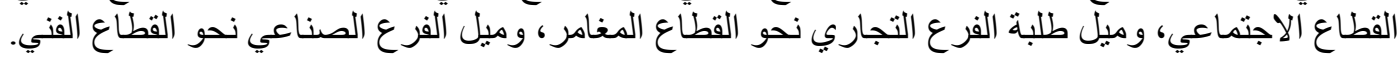

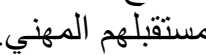

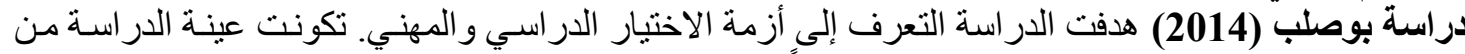

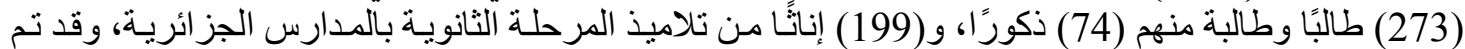

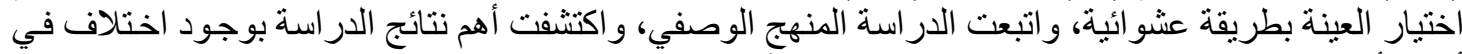

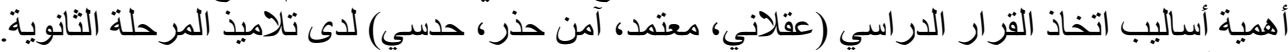

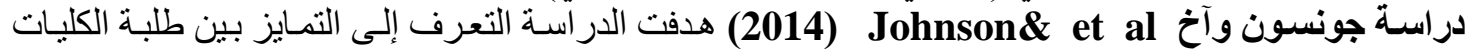

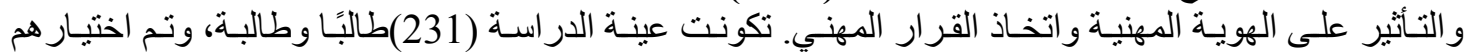

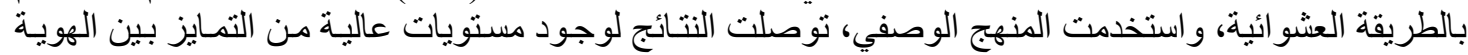

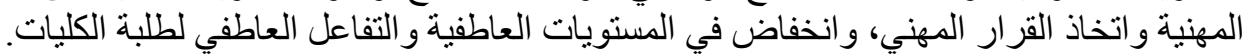

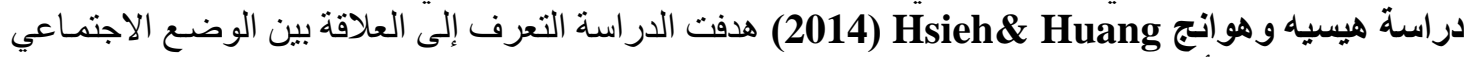

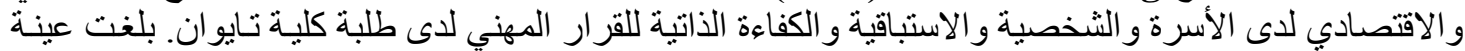

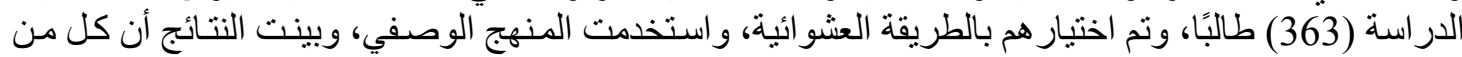

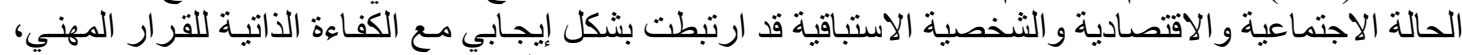

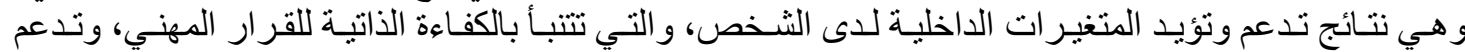

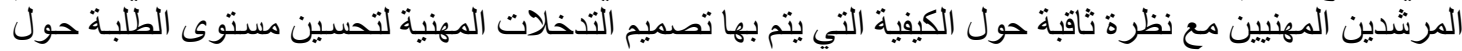
الكفاءة الذاتية للقرار المهني. دراسة العزيزي (2011) هدفت الدر اسة التعرف إلى أثر برنامجي إرشادي لنظريتي (هولاند وسوبر) في تحسين

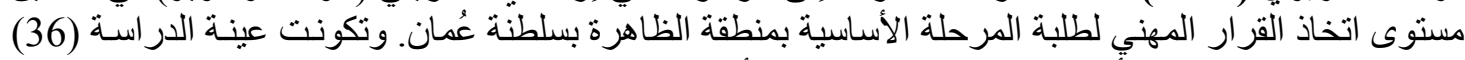

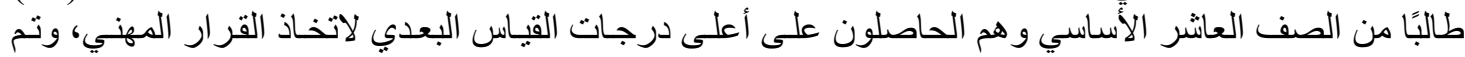

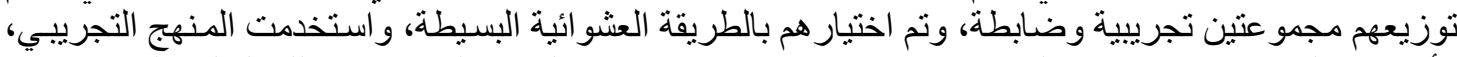

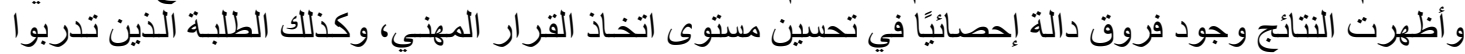

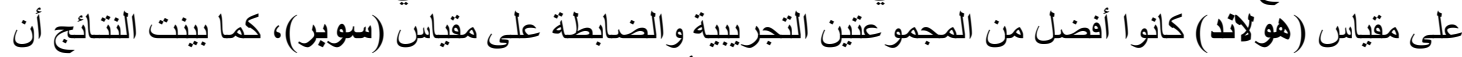

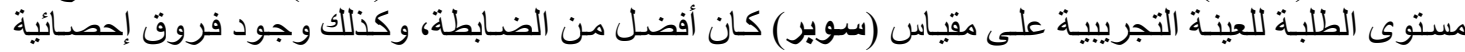
لصالح المجمو عة التجريبية.

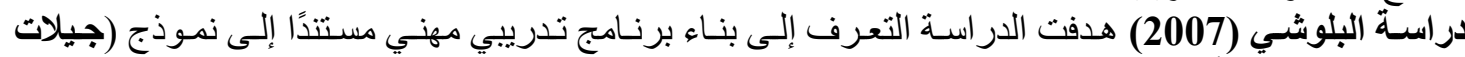

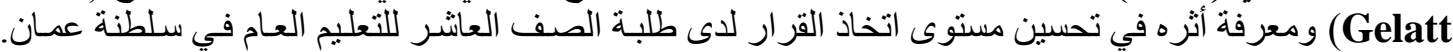

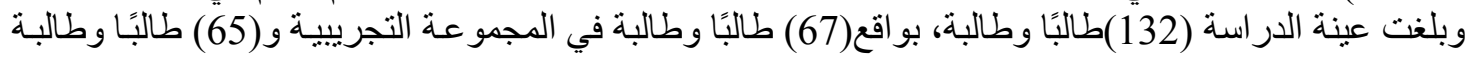

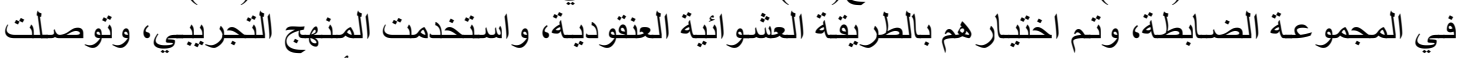

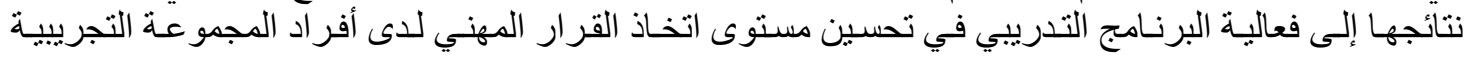




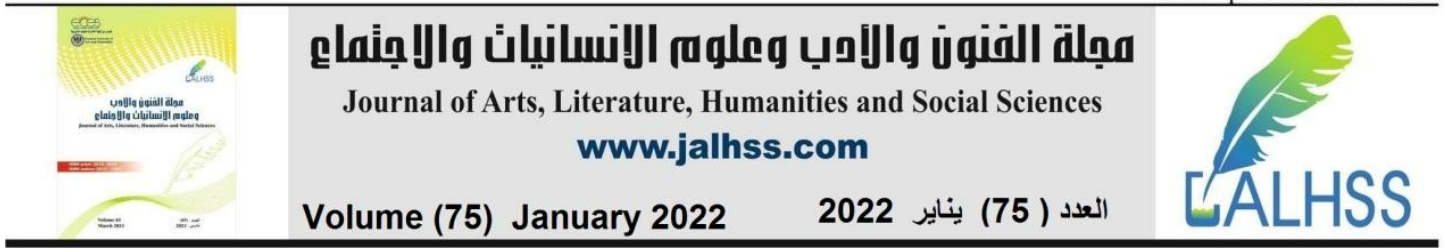

ولصـالح الإنـاث، وأسفرت عن عدم وجود أثر للتفاعل بين البرنـامج ومستوى تعليم الو الدين في اتخـاذ القرار

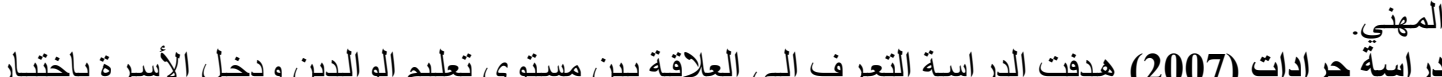

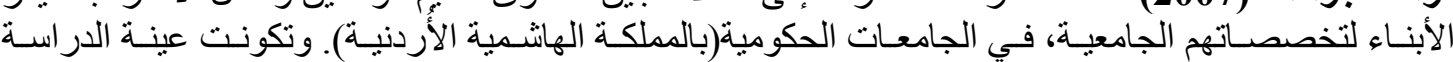

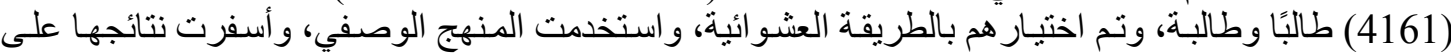

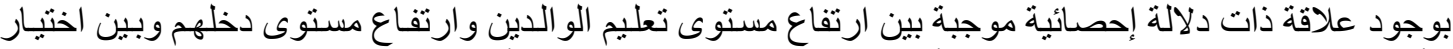

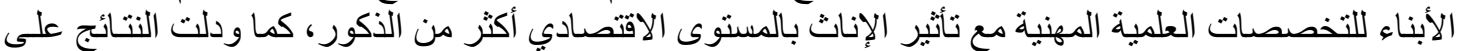

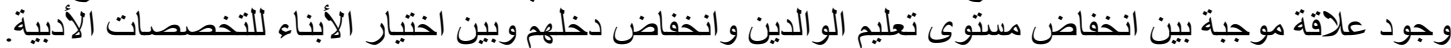
دراسة جيرميزي وفيرستشيرن Germeijs \& Verschueren (2006) هدفت الدراسة التعرف إلى الكثنف

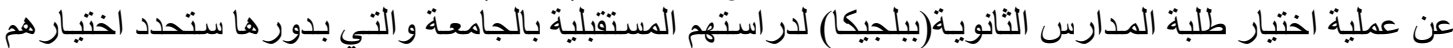

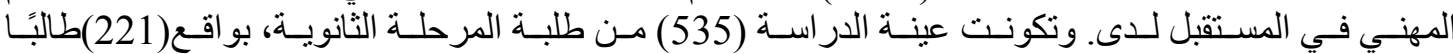

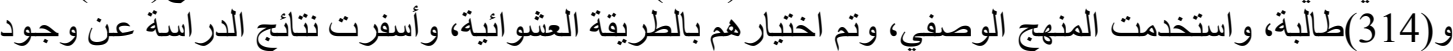

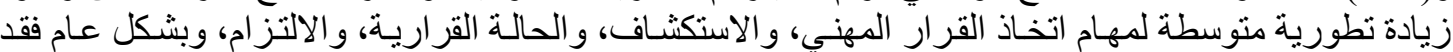

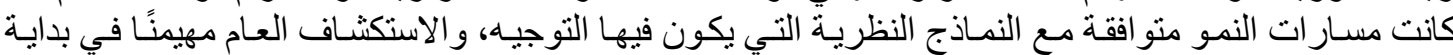

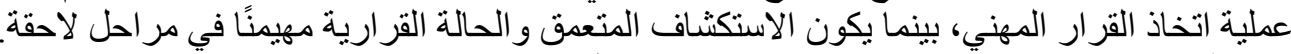

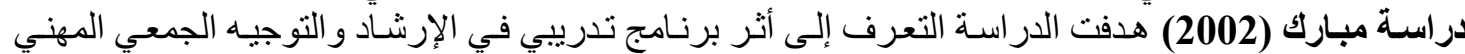

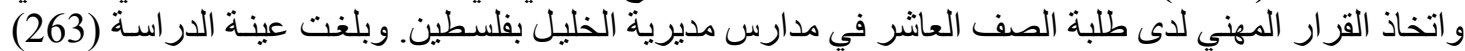

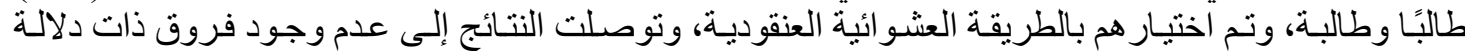

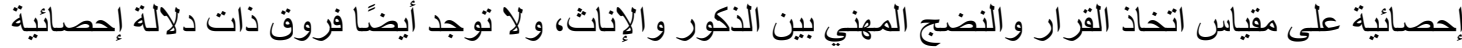

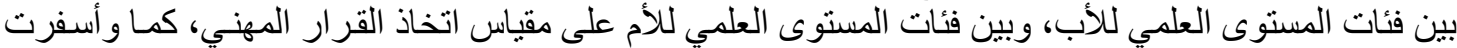

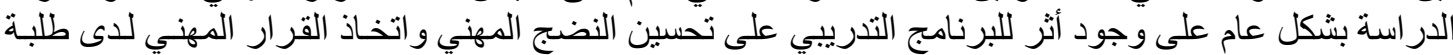

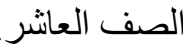

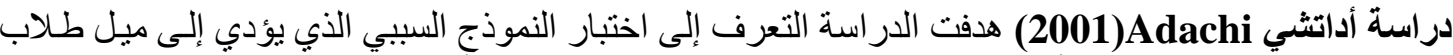

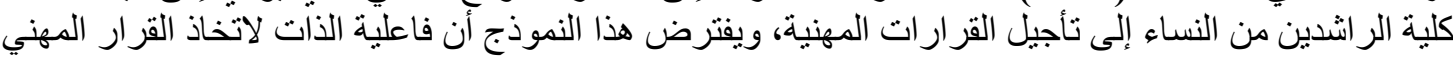

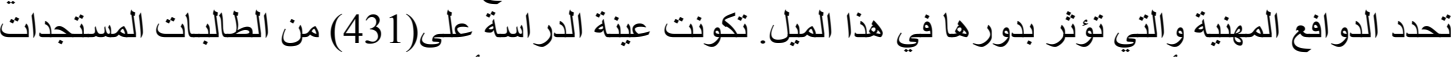

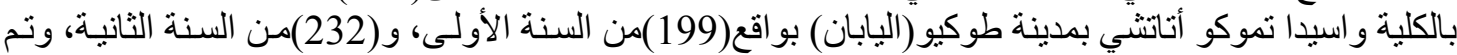

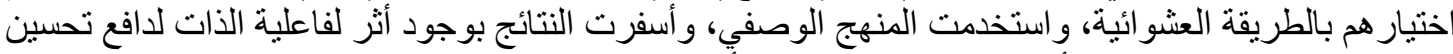

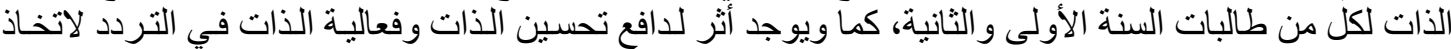

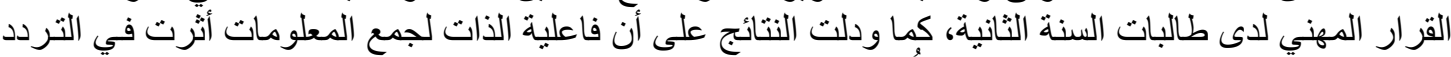

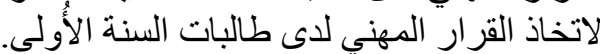
دراسة هميسات والبدور(1999) هدفت التعرف على الإلى أثر كل من مستوى التحصيل و التفضيل المهني، ومهن

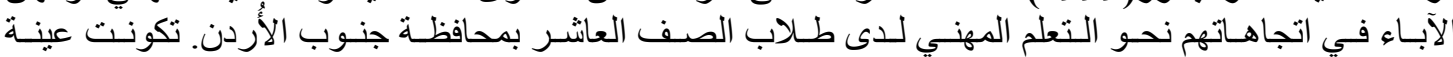

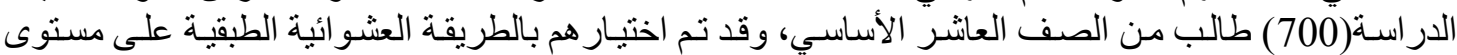

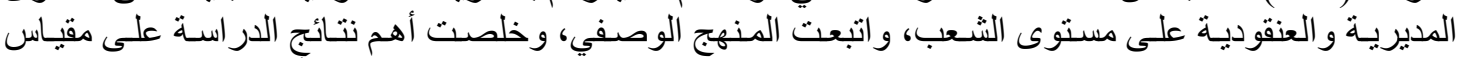

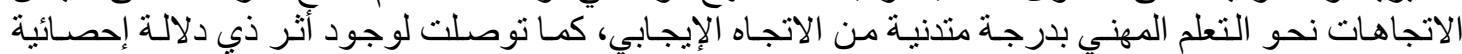

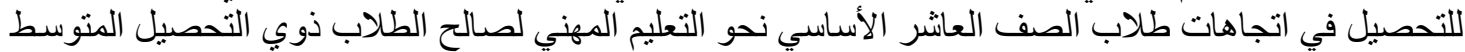

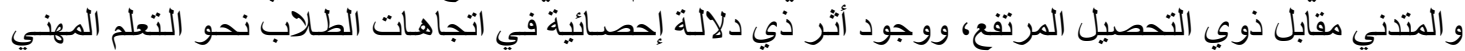

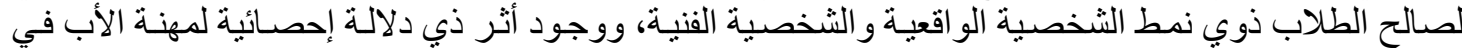
اتجاهات الطلاب نحو التعلم المهني لصالح الطلاب الذين يعمل آباؤ هم في المهن اليدوية الئلة العملية.

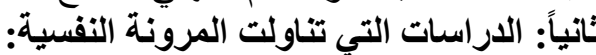

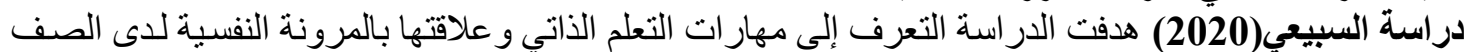

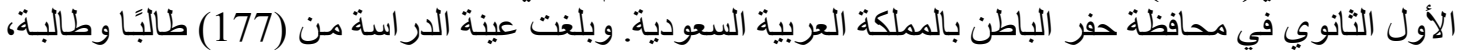

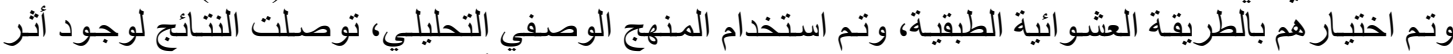

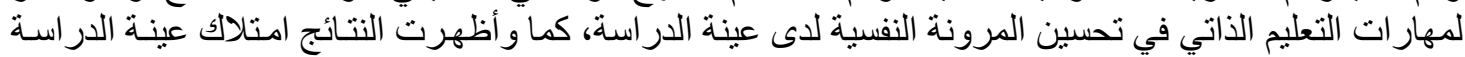




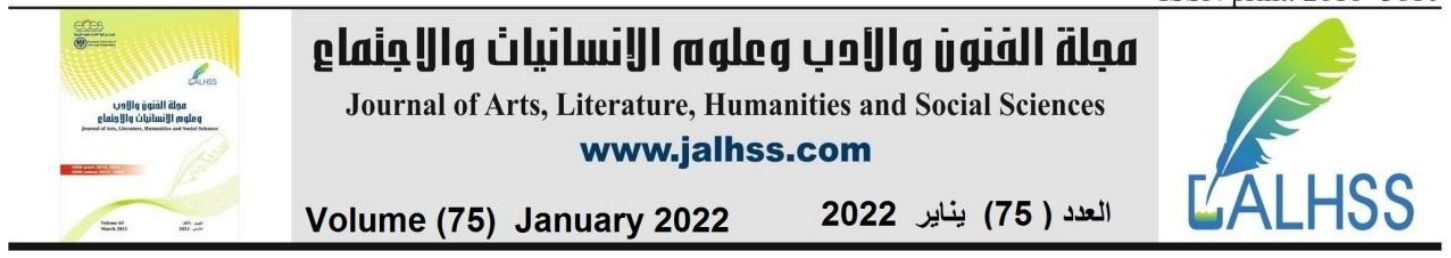

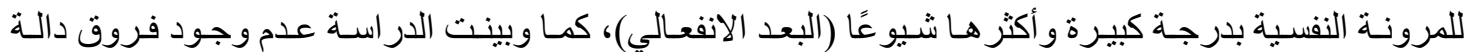

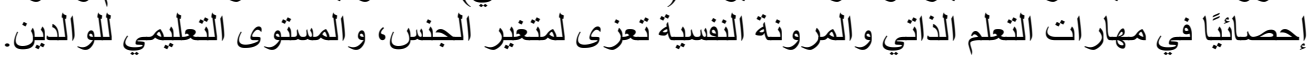

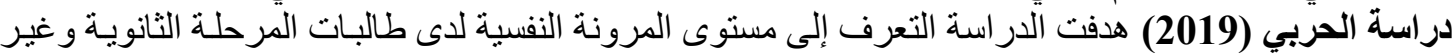

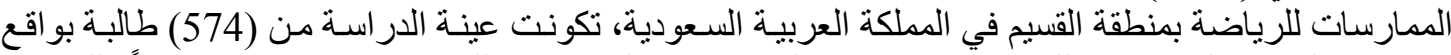

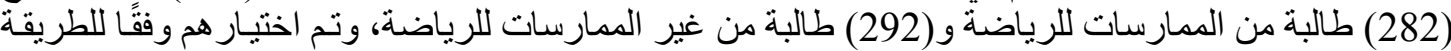

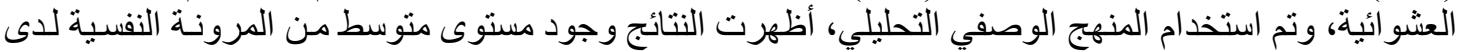

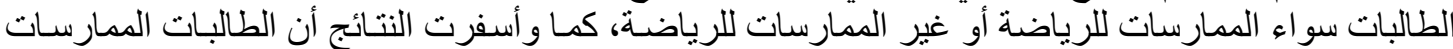

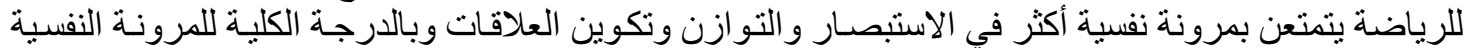

من الطالبات غير الممارسات للرئة

دراسة الحساسنة وداود (2018) هدفت الدر اسة التعرف إلى مستوى العنف العدة المدرسي و وعلاقته بالمرونـة النفسية

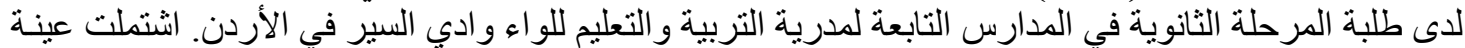

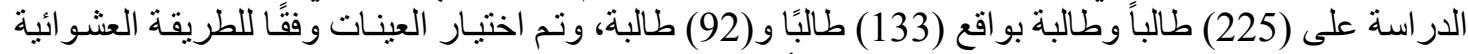

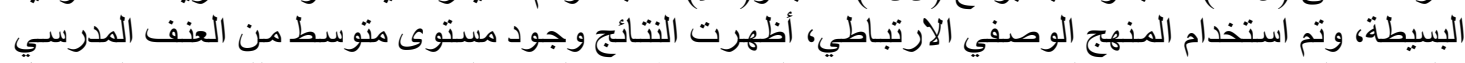

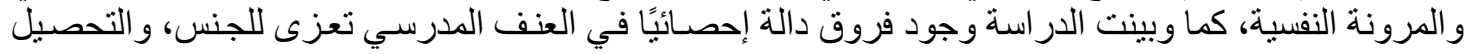

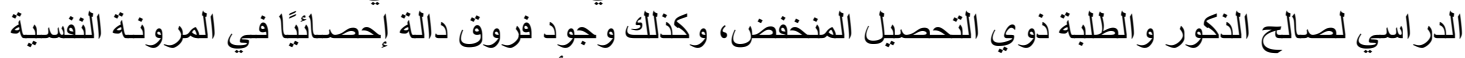

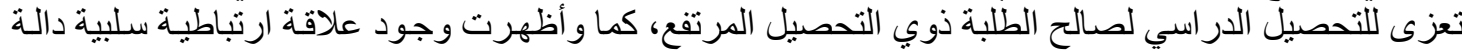
إحصائيًا بين العنف المدرسي و المرونة النين النفية. دراسة حسن (2018) هدفت التعرف على القدرة التنبؤية للمرونة النفسية ومستوى الطموح و المثنابرة الأكاديمية

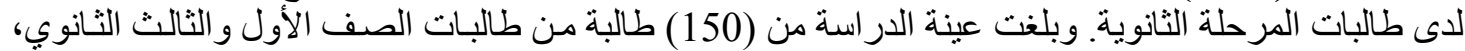

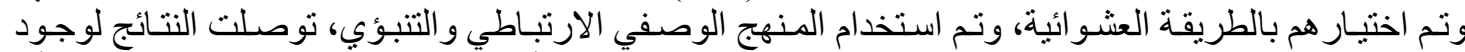

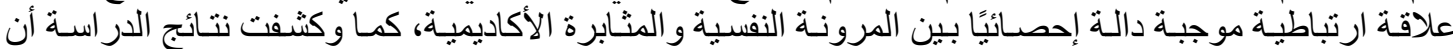

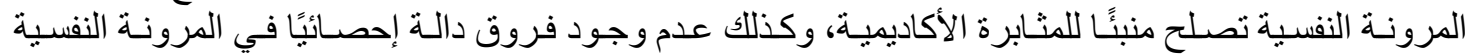

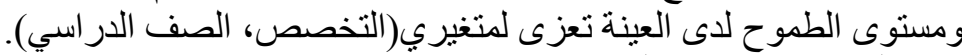

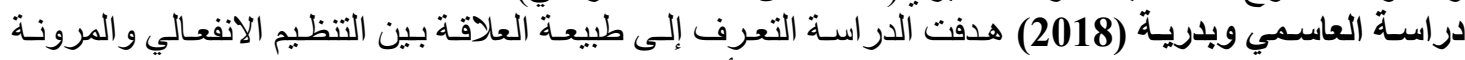

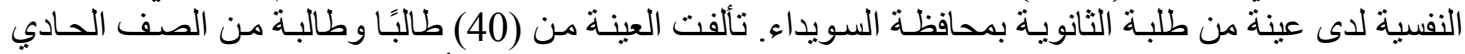

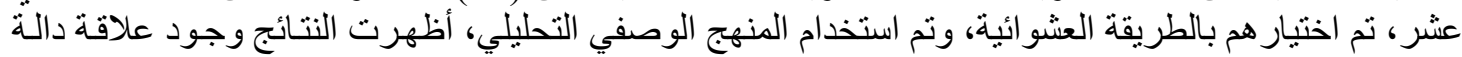

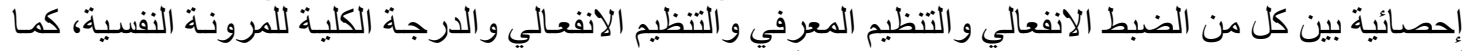

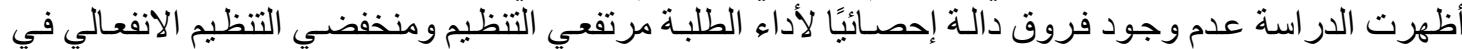

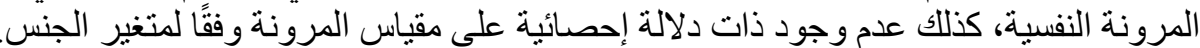

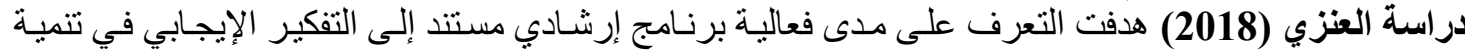

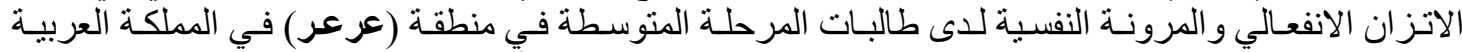

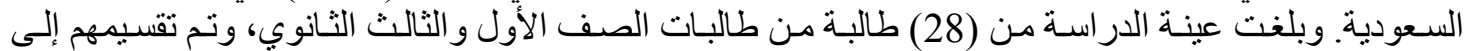

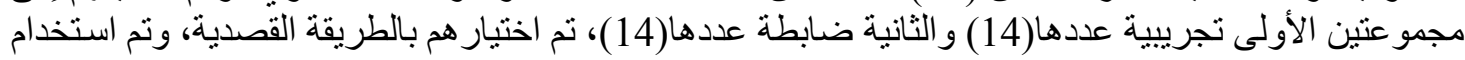

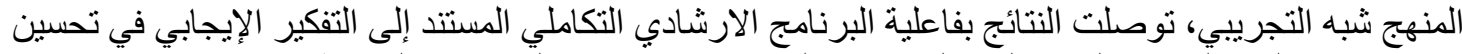

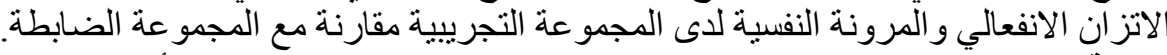

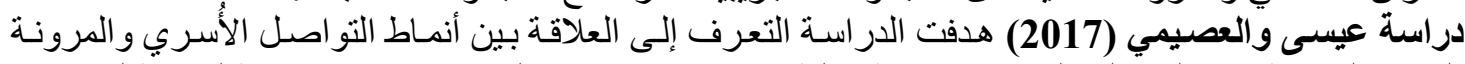

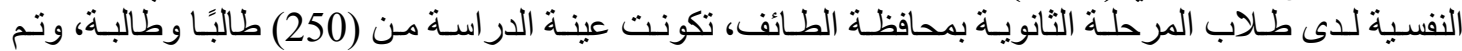

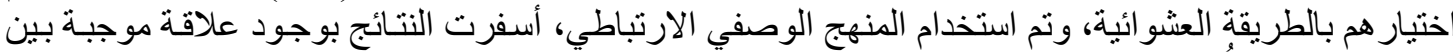

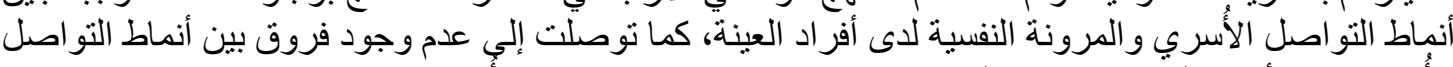

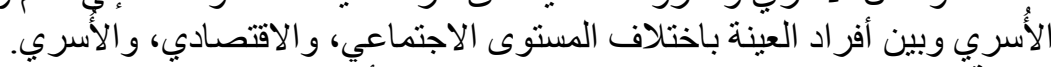

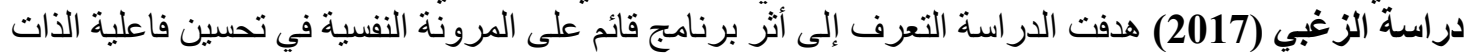

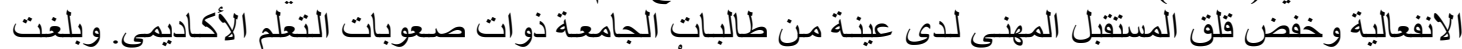

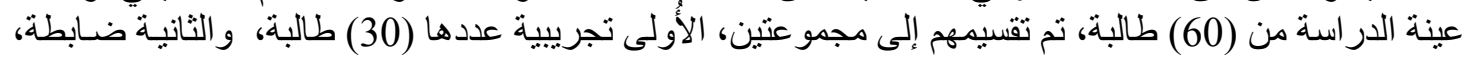
و عددها(30) طالبة، ونم اختيار هم بالطريقة القصدية، ونم استخدام المنهج شبه التجريبي، أظهرت التربة النتائج وجود 


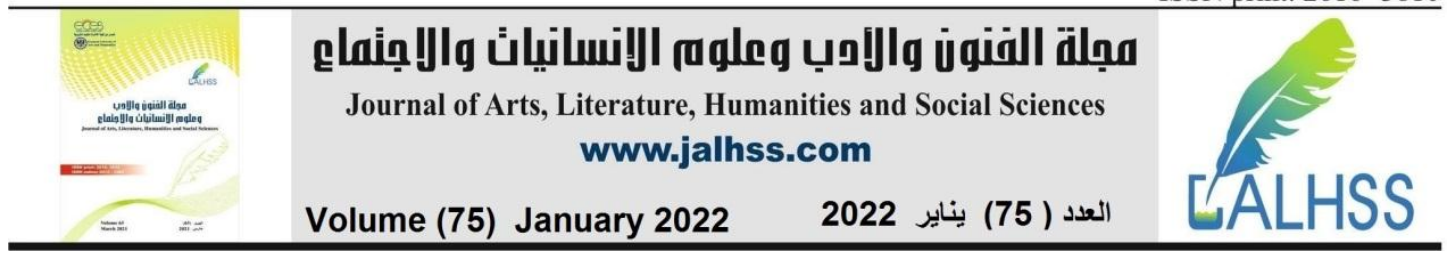

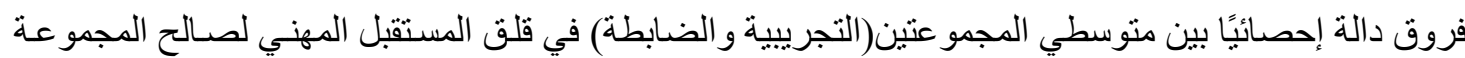

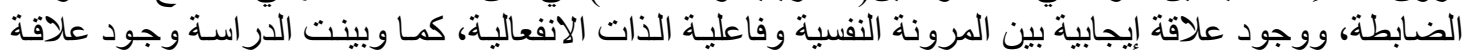

ارتباطية سالبة بين المرونة النفسية ومستوى القلق و التونة التوتر والفين والإحباط.

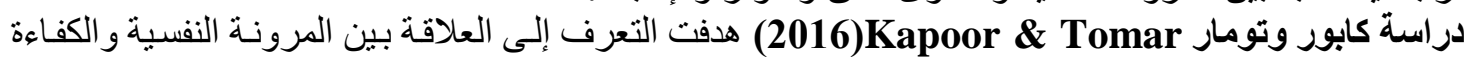

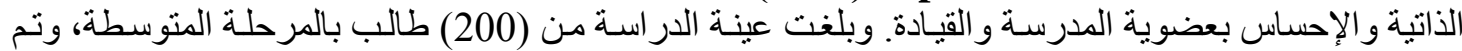

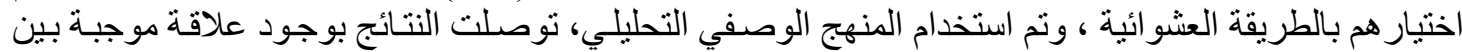

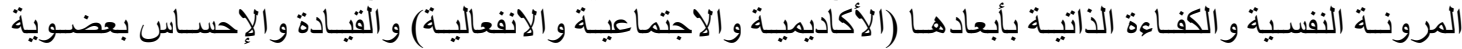
المدرسة. دراسة: نوفنتي وكريمونكوفا Novotny\& Kremenkova (2016) هدفت الدر اسة التعرف إلى العلاقة بين

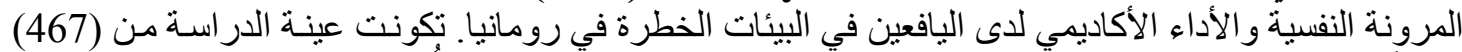

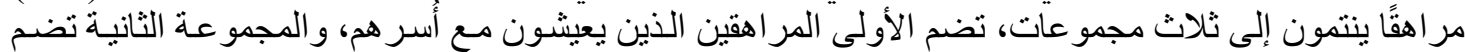

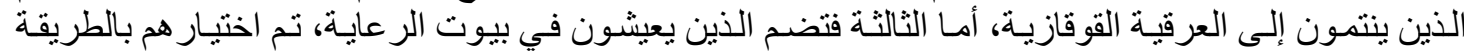

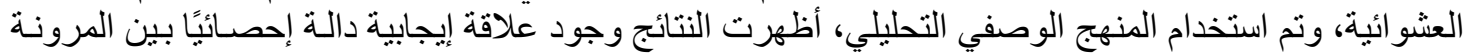

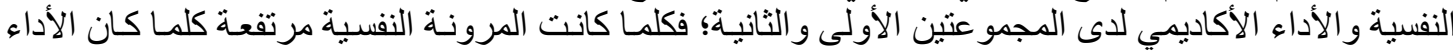

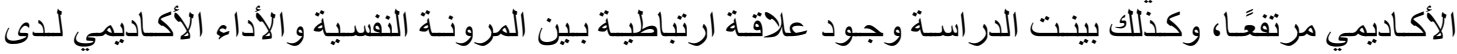

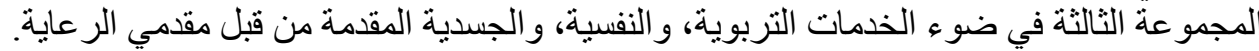

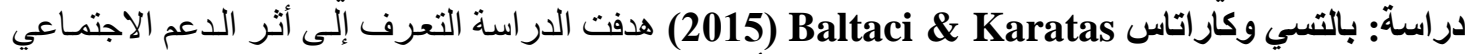

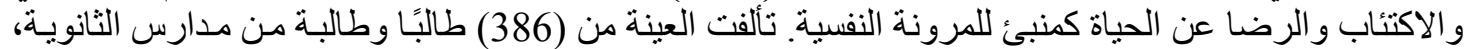

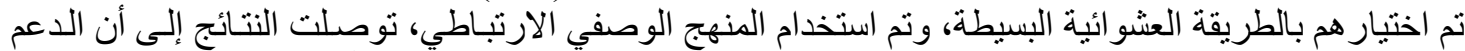

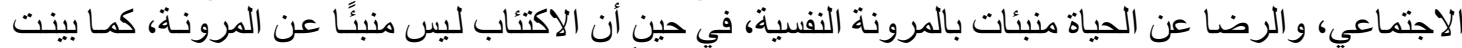

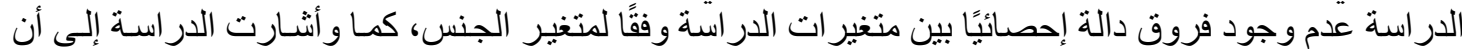

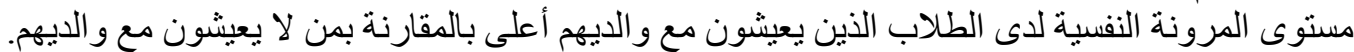

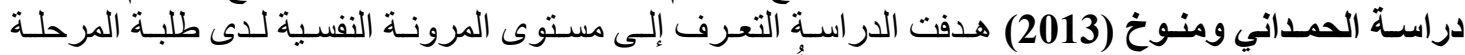

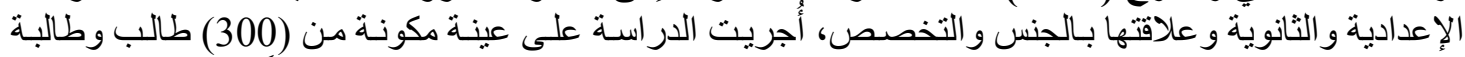

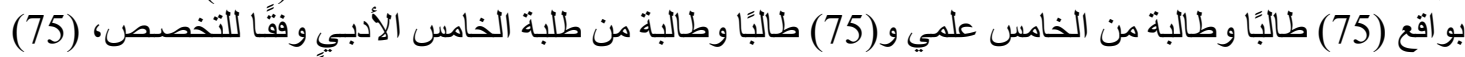

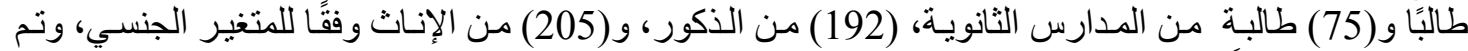

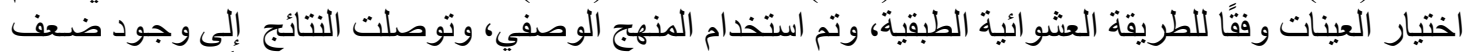

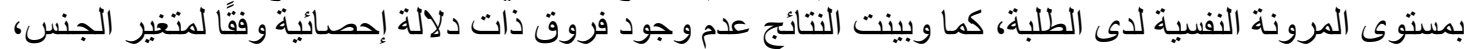

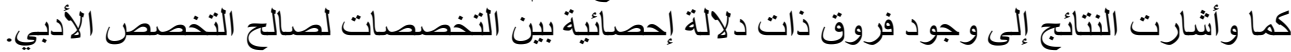

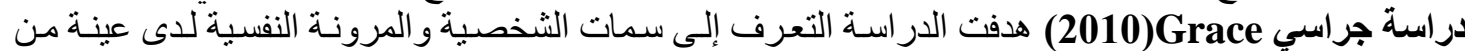

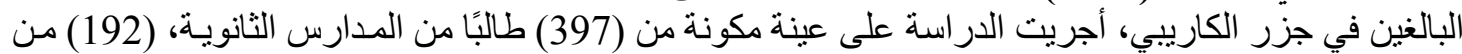

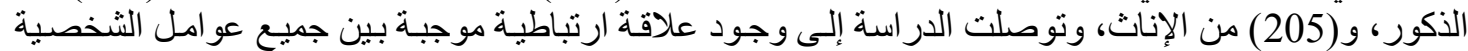

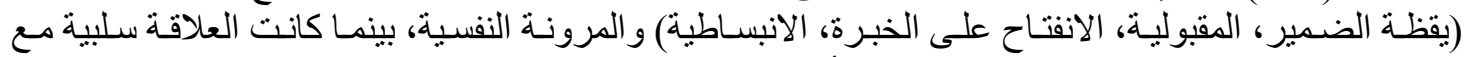

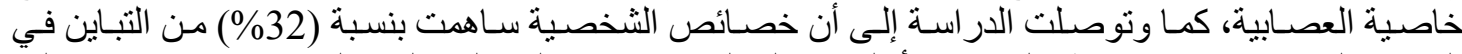

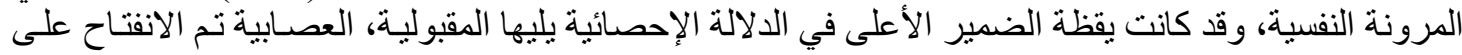

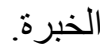
دراسـة سبينت

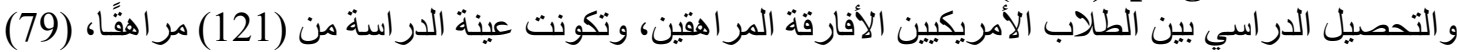

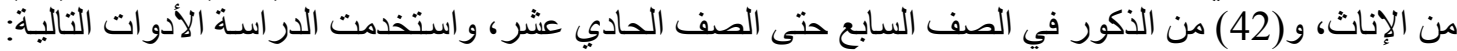

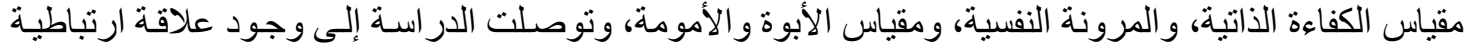

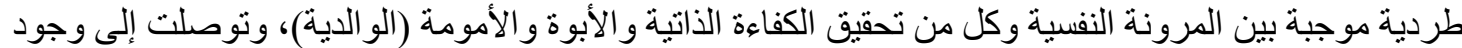

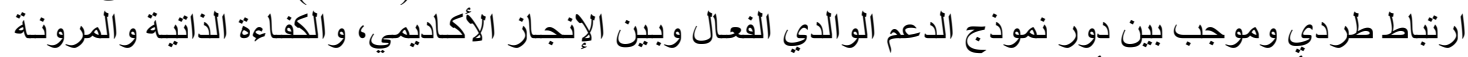

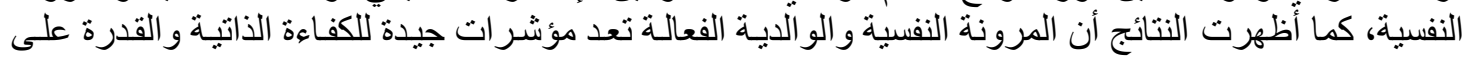




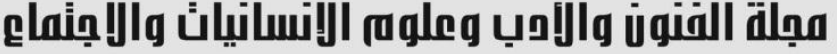

Journal of Arts, Literature, Humanities and Social Sciences www.jalhss.com

مشكلة الاراسة : ميكة

تتمحور مشكلة الدارسـة الحاليـة في السؤال الرئيس الآتي: مـا علاقة الاختيـار المهني بالمرونـة النفسية لاى

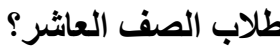

وينبثق عنه التساؤلات الفرعية الآتية:

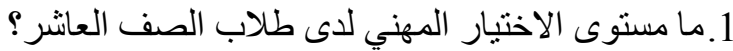

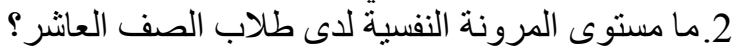

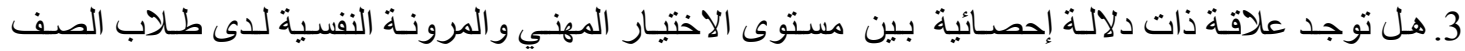

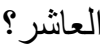

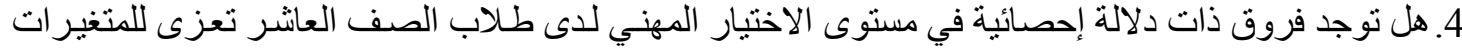

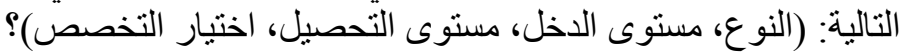

5. هل توجد فروق ذات دلات دلانة إحصائية في مستوى المرونة النفسية لدى طلاب الصف الصف العاثر تعزى للمتغيرات

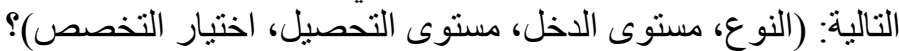

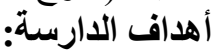

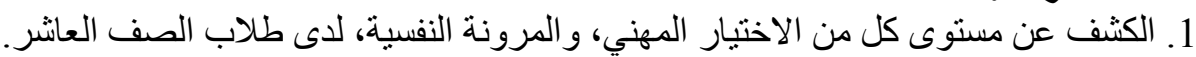

2. التعرف إلى العلاقة الإحصائية بين مستوى الاختيار الإنيار المهني و المرونـة النفسية، وبين مستوى الاختيار المهني

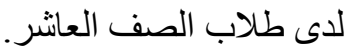

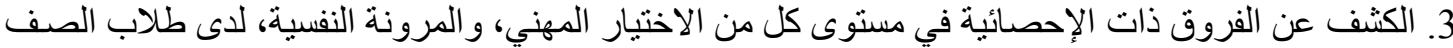

العانشر تعزى للمتغير ات التالية: (النوع، مستوى الآنل، مستوى التحصيل، اختيار التخصص).

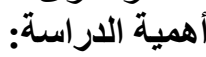

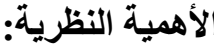

1.سعي الدر اسة لتقديم إطار نظري يتناول الاختيار المهني و المرونة النفسية.

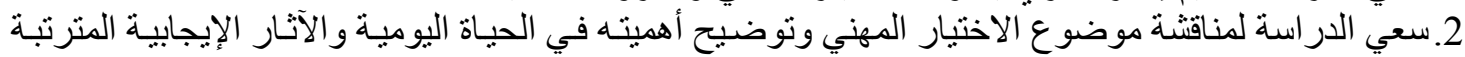

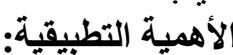

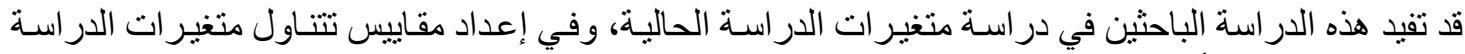

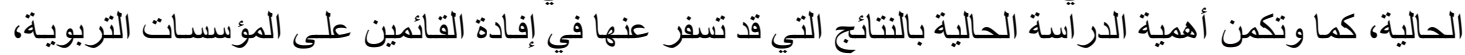

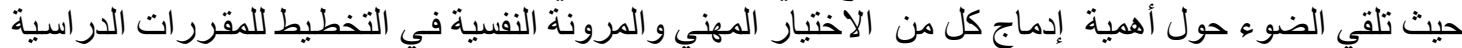

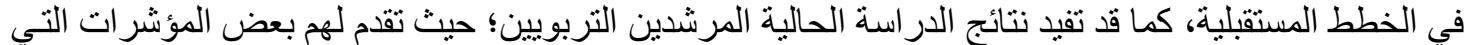

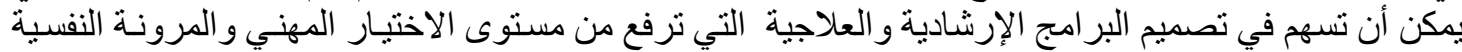

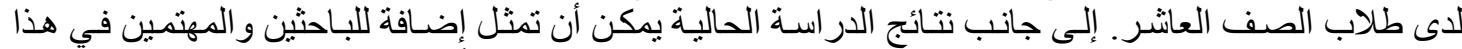

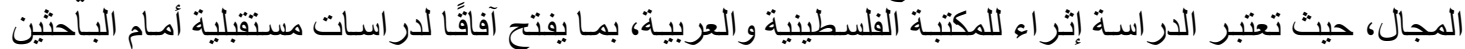

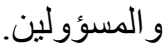

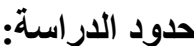

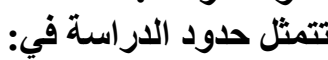

1-الحد الموضوعي: تقتصر الدر اسة على الكثف عن العلاقة بين الاختيار المهني و المرونـة النفسية لدى طلبة

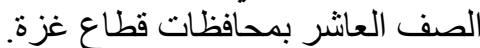

3-الحد الزماني: سوف يتم إجر اء هذه الدر اسة في العام الدراسي (2021-2022م).

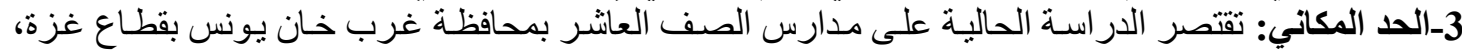

فلسطين.

4-الحد البشري: طلاب الصف العاثر الأساسي بمدارس محافظة غرب خان يونس.

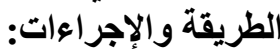

منهج الدراسة: اتبعت الدراءتة استة المنهج الوصفي، كونه من أنسب المناهج في الدراسات و البحوث الإنسانية، ويقوم

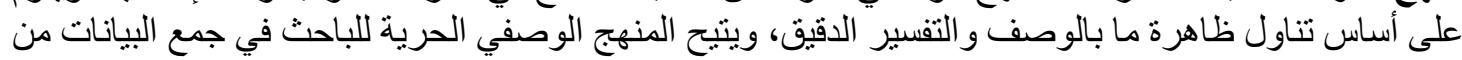




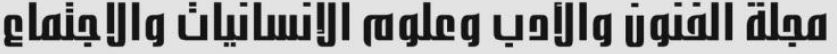

Journal of Arts, Literature, Humanities and Social Sciences www.jalhss.com

مصادر ها الخاصةة، والتفاعل مع هذه البيانات من أجل تبويبها وتحليلها وصولًا لنتائج وتعميمات و علاقات تفيد في حل مشكلة الدر اسة. مجتمع الدراسة: يتكون شمل ملثة المجتمع الأصلي للار اسة الحالية، جميع طلبة المستوى الدراسي العاثر في

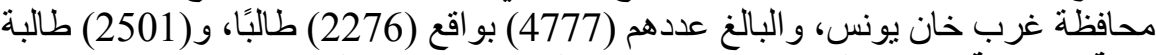

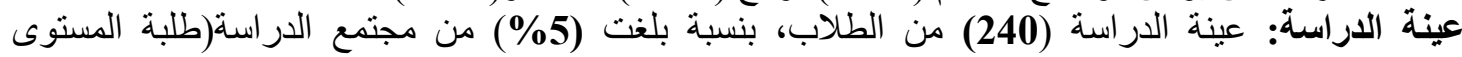
الدر اسي العاشر بمحافظة غرب خان يونس، للعام 2021 / 2022 م)، حيث تم اختيار هم بطريقة العينة العشوائية من المجتمع الأصلي للار اسة. ونوضح الجداول التالية الخصائص الإحصائية لعينة الدراسة.

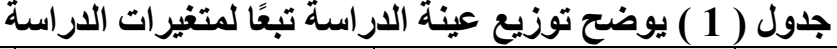

\begin{tabular}{|c|c|c|c|}
\hline النسبة المئوية & العدد & البيان & المتغير \\
\hline 49.2 & 118 & ذكر & \multirow{2}{*}{ النوع } \\
\hline 50.8 & 122 & أنثى & \\
\hline 16.3 & 39 & منخفض & \multirow{3}{*}{ مستوى الاخل } \\
\hline 70.4 & 169 & متوسط & \\
\hline 13.3 & 32 & مرتفع & \\
\hline 3.8 & 9 & مقبول & \multirow{4}{*}{ مستوى التحصيل في } \\
\hline 17.5 & 42 & جيد & \\
\hline 27.9 & 67 & جيد جدًا & \\
\hline 50.8 & 122 & ممتاز & \\
\hline 47.1 & 113 & علمي & \multirow{4}{*}{ اختيارك التخصص } \\
\hline 42.5 & 102 & أدبي & \\
\hline 5.4 & 13 & مهني & \\
\hline 5.0 & 12 & شرعي & \\
\hline$\% 100$ & 240 & & \\
\hline
\end{tabular}

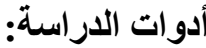

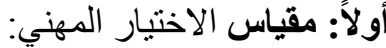
قام الباحث بإعداد مقياس الاختيار المهني بعد الاطلاع على مفهوم الاختبار المهني في الأدبيات التربوية و النفسية الإنية

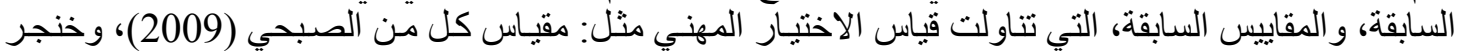

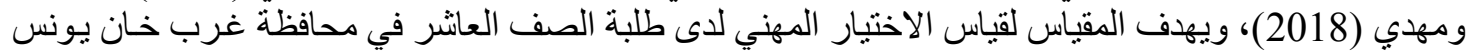

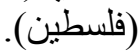

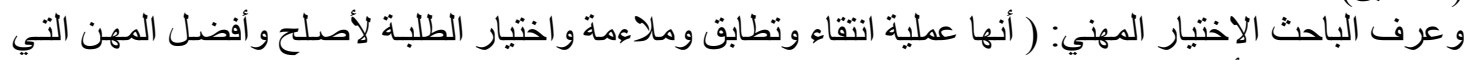

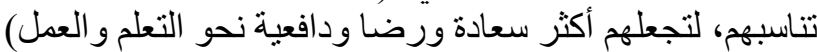

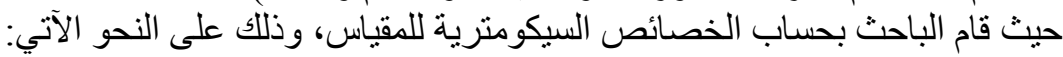

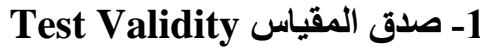
للتأكد من صدق المقياس المقياس؛ تم استخدام طرق عدة، هي: أ - صدق المحتوى Content Validity

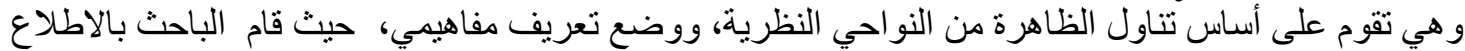

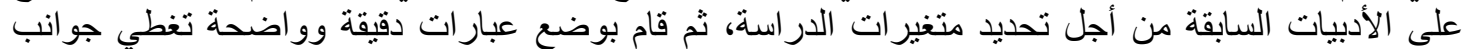

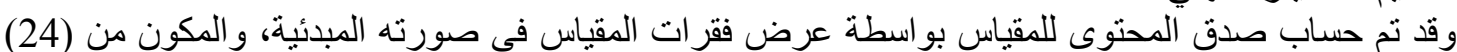

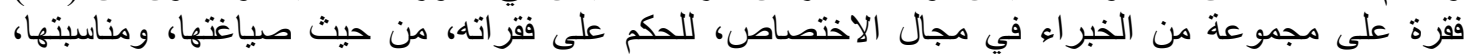




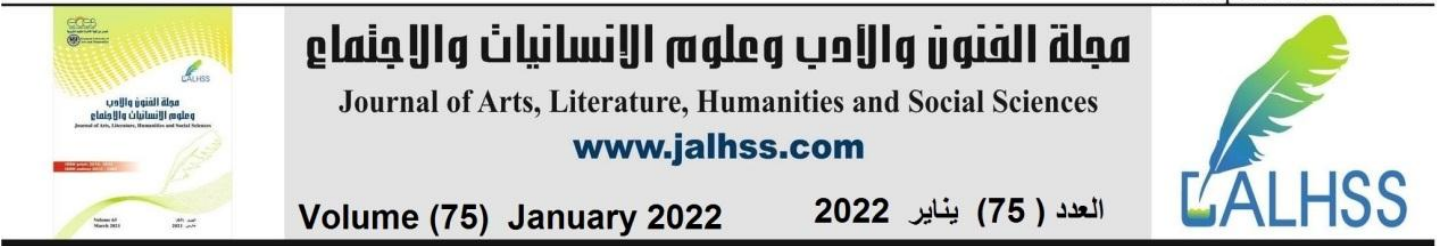

وملاءمتها لقياس ما وضعت من أجله، وبقي المقياس بعد إجر اء تعديلات، وتوجيهات المحكمين يتكون من(23)

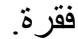

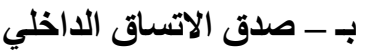

يقصد به: "مدى احتو اء المقياس بنودًا(فقرات) منسقة الإجابة عنها؛ فهي تقيس جميعها الوظيفة (السمة) نفسها،

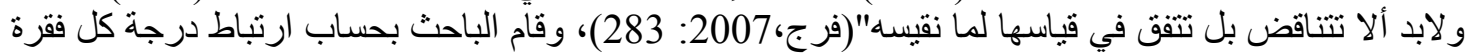

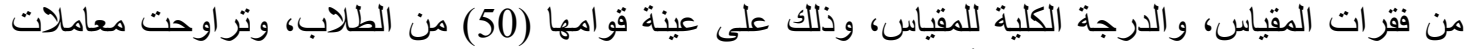
الارتباط بين (0.596 - 0.895)، وأن جميع فقرات الات المقياس دالة إحصائيًا عند مسنوى 0.

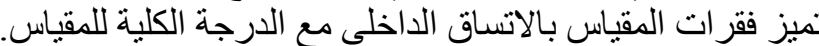
2 - ثبات المقياس Test Reliability يقصد بثبات المقياس، ثبات و استقر ار نتائجها، ويعتبر المقياس ثابنًا إذا تم

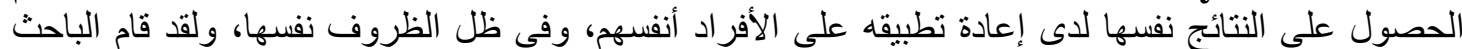

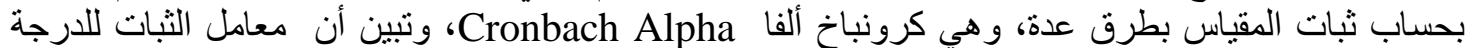

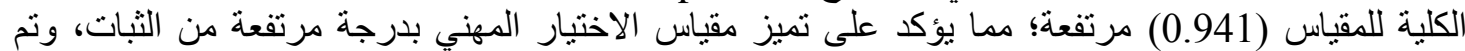

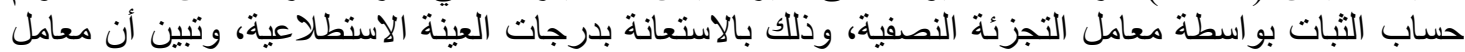

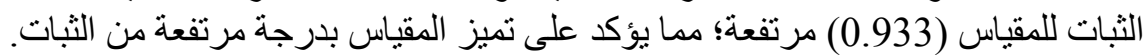
ثانياً - مقياس المرونة النفسية

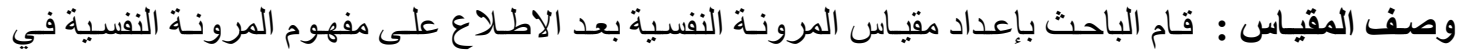

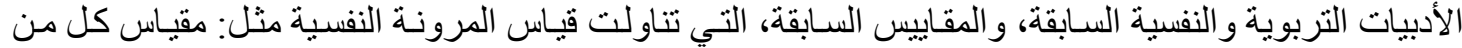

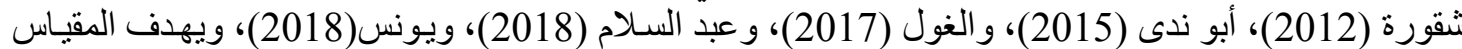

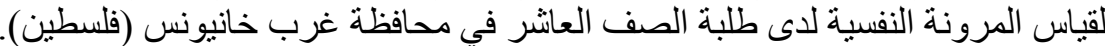

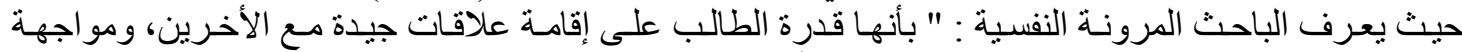

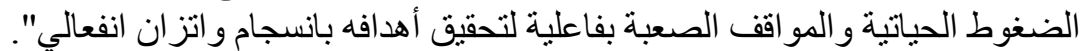
ومن تم قام الباحث بحساب الخصائص السيكومترية للمقياس، وذللك على النحو الآتي:

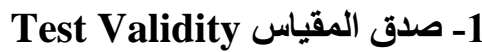
لأجل التاككد من صدق المقياس؛ تم استخدام طرق عدة، هي:

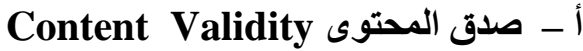

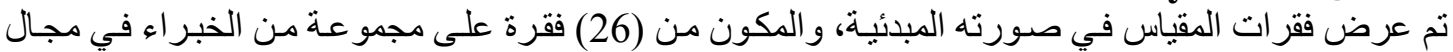

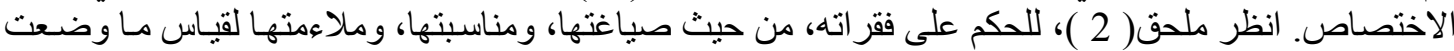
من أجله، وبقي المقياس بعد إجر اء تعديلات، وتوجيهات المحكمين يتكون من(26) فقرة.

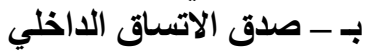
قام الباحث بحساب ارتباط درجة كل فقرة من فقرات المقياس، والدرجة الكبات الكلية للمقياس، وذلك على عينة قوامها

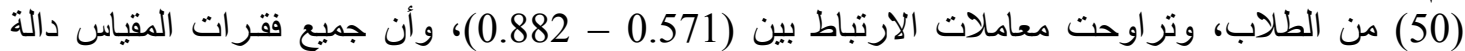

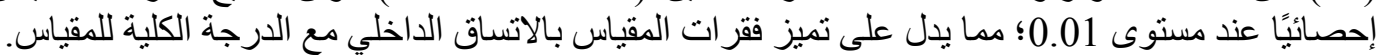

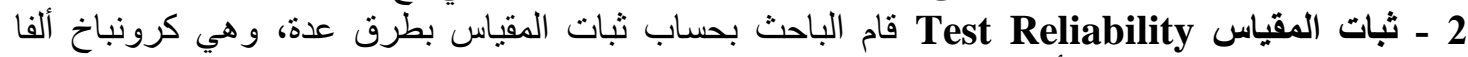
Cronbach Alpha

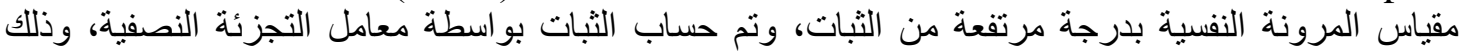

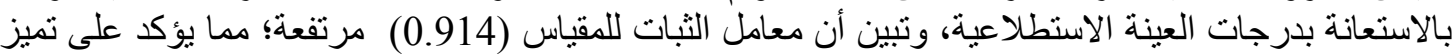
المقياس بدرجة مرتفعة من الثبات.

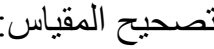
تم بعد ذلك حساب المتوسط الحسابي المرجع ثم يحدد الاتجاه حسب قيم المتوسط المرجح كما في جدول رقم ( 2). 


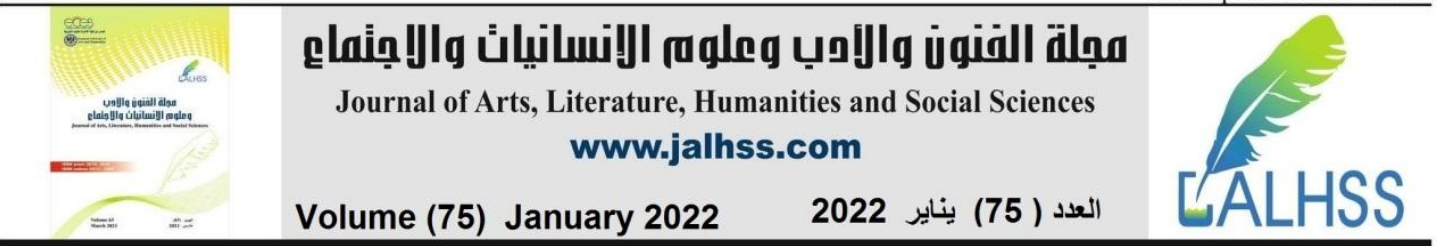

\begin{tabular}{|c|c|c|}
\hline \multicolumn{3}{|c|}{ جدول ( 2) المحك المعتمد في الدراسة } \\
\hline درجة التأييد & الوزن النسبي & المتوسط الحسابي \\
\hline منخفض جدًا & $\% 36-\% 20$ & $1.80-1$ \\
\hline منخفض & أكبر من 36\% - 52\% & أكبر من 1.80 - 2.60 \\
\hline متوسطة & أكبر من 52\% - 68\% & أكبر من 2.60 - 3.40 \\
\hline مرتفع & أكبر من 68\% - 84\% & أكبر من 3.40 - 4.20 \\
\hline مرتفع جدًا & أكبر من 84\% - 100\% & أكبر من 4.20 - 5 \\
\hline
\end{tabular}

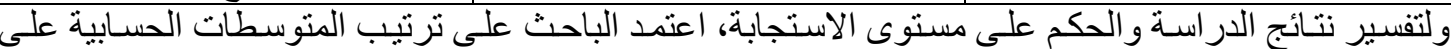

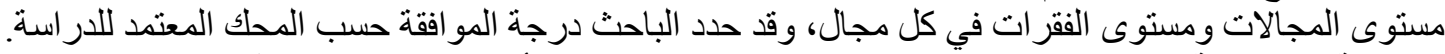

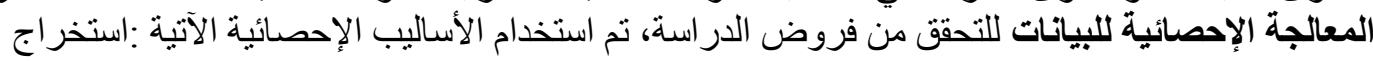

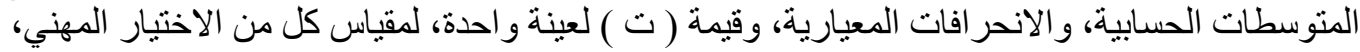

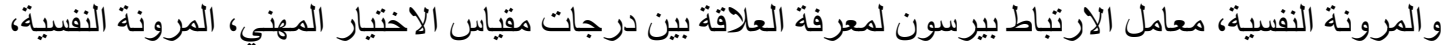
اختبار "ت" لعينتين مستقلتين، اختبار التباين الأحادي للعينات المستقلة.

عرض وتفسير نتائج السؤال الأول

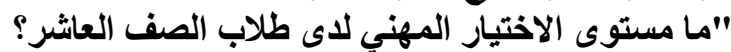

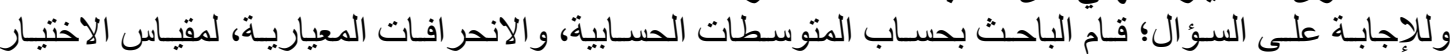
المهني، كما هو مبين في الجدوابـ الجدول الآتي. جلول(3) المتوسطات الحسابيةً والانحر افات المعيارية للكثف عن مستوى مقياس الاختيار المهني.

\begin{tabular}{|c|c|c|c|c|}
\hline المستوى & النسبي & المعياري & الحستوسي & مقياس الاختيار المهني \\
\hline مرتفع & 81.14 & 0.555 & 4.06 & الدرجة الكلية للمقياس \\
\hline
\end{tabular}

يتضح من الجدول السابق أن مستوى الاختيار المهني (81.41\%) وهو مستو مستوى مرتفع.

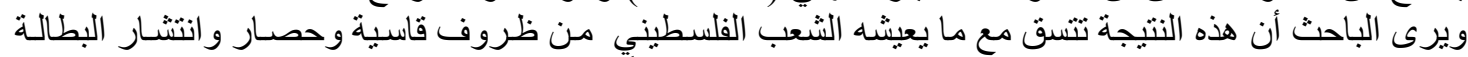

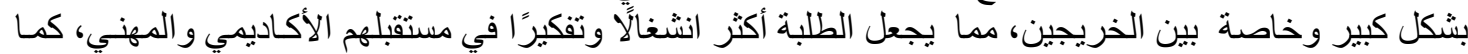

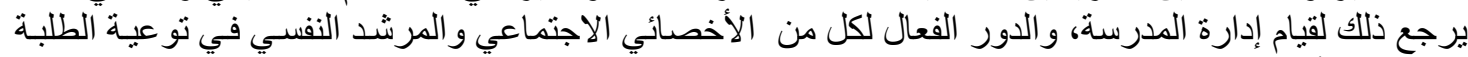

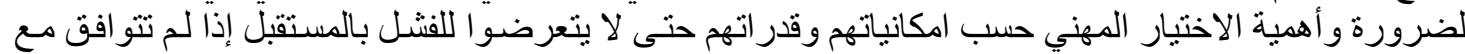

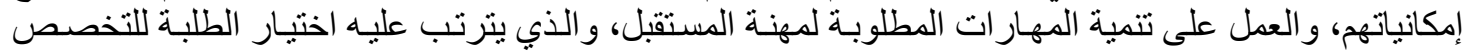

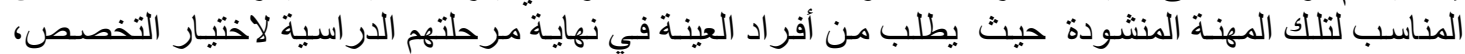

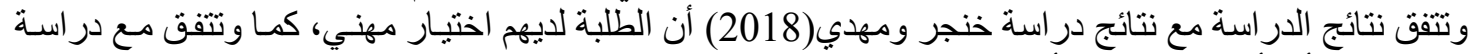

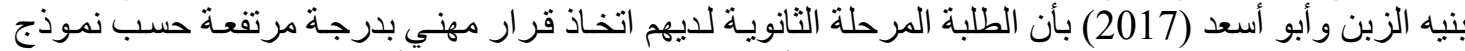

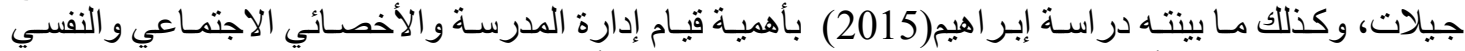

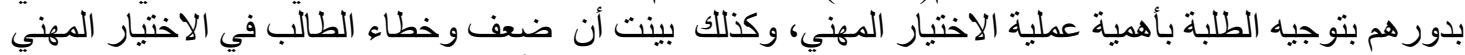

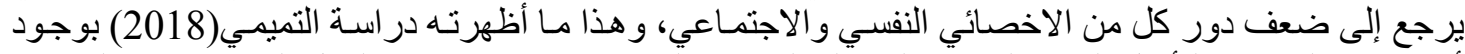

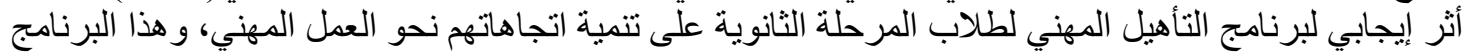
يعتبر من صميم عمل الاخصنيائي. عرض وتفسير نتائج السؤال الثناني : ما مستوى المرونة النفسية لدى طلاب الصف الصف العاثر؟

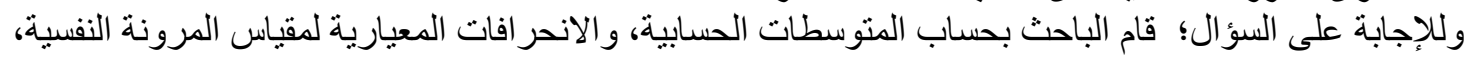
كما هو مبين في الجدول الآتي. 


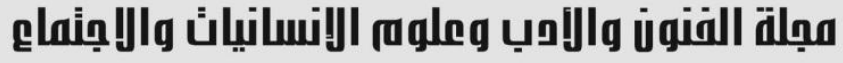

Journal of Arts, Literature, Humanities and Social Sciences www.jalhss.com

Volume (75) January 2022

العدد ( 75) يناير 2022

جدول(4)المتوسطات الحسابية والاتحرافات المعيارية للكثف عن مستوى مقياس المرونة النفسية

\begin{tabular}{|c|c|c|c|c|}
\hline المستوى & النسبي & المعياري & الحستبي & مقياس المرونة النفسية \\
\hline مرتفع - مرتع & 83.118 & 0.548 & 4.16 & الدرجة الكلية للمقياس. \\
\hline
\end{tabular}

يتضح من الجدول السابق أن الوزن النسبي للارجة الكلية للمقياس (83.1\%) وهو مستوى مرتفع.

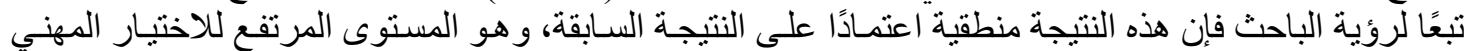

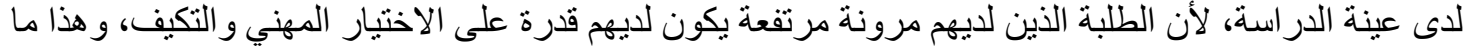

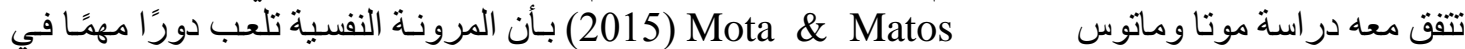

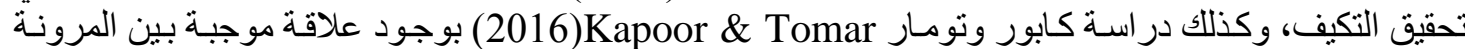
النفسية و الكفاءة الذاتية بأبعادها (الأكاديمية و الاجتماعية و الانفعالية).

السؤال الثالث: هل توجد علاقة ذات دلالة إحصائية بين مستوى الاختيـار المهنـي والمرونـة النفسية لدى طلاب

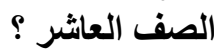
وينبيثق من السؤال الفرضية التالية:

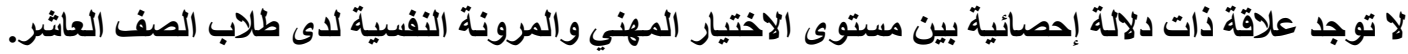

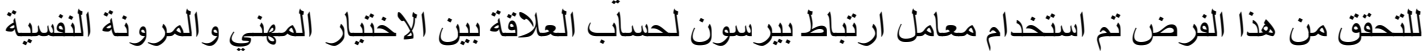

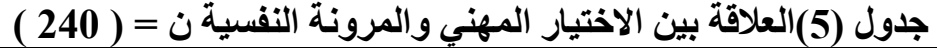

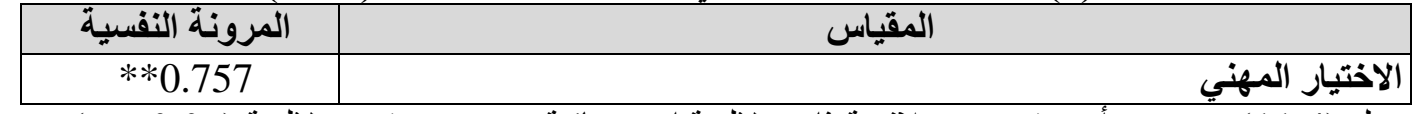

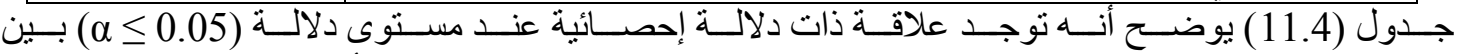

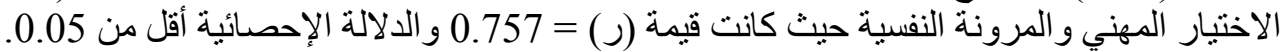

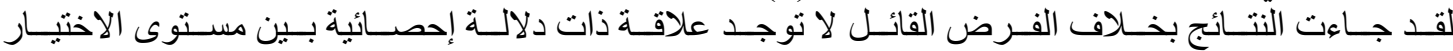

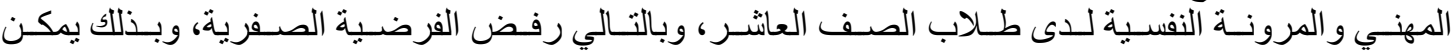

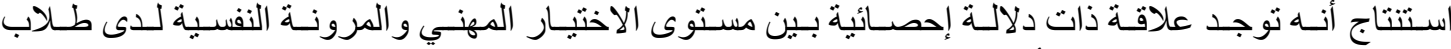

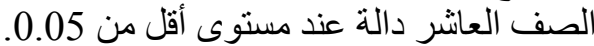

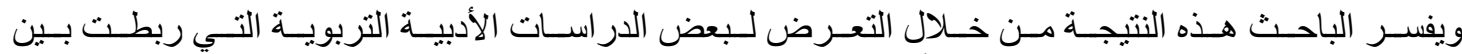

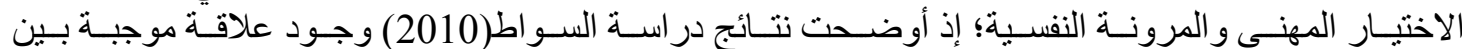

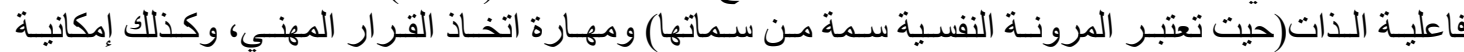

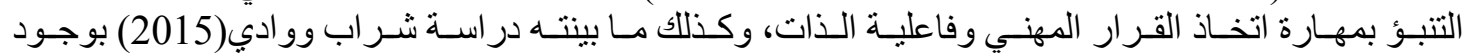

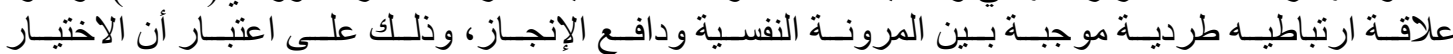

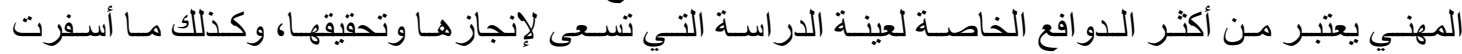

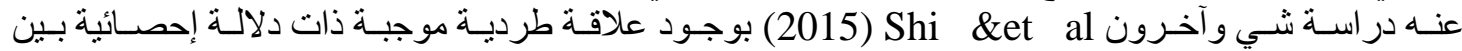

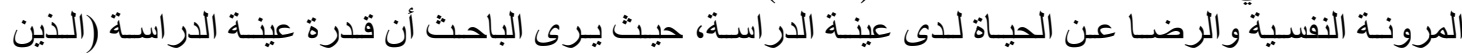

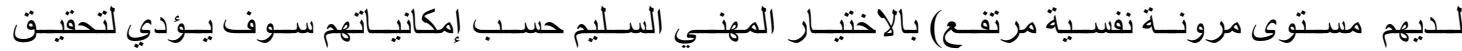

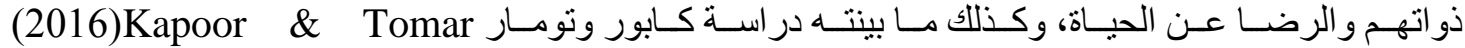

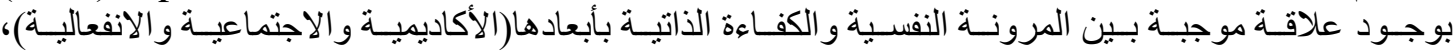

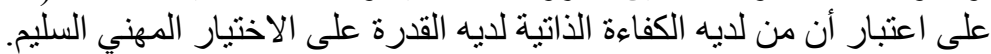

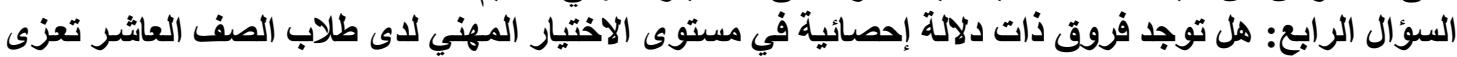

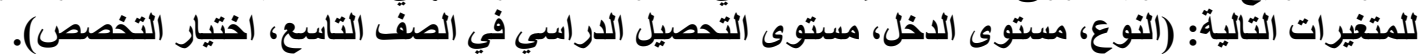
وينبثق من السؤال الفرضيات التوع التالية:

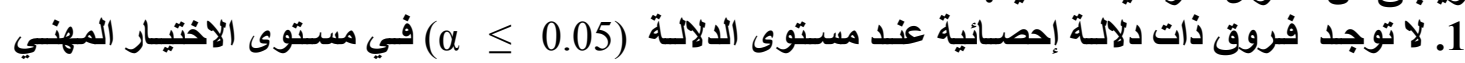

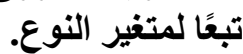
استخدم الباحث اختبار "تو للتعرف على الفروق بين المجمو عتين 


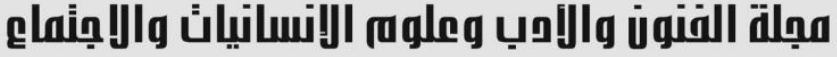

Journal of Arts, Literature, Humanities and Social Sciences www.jalhss.com

Volume (75) January 2022

العدد ( 2022 العاير

\begin{tabular}{|c|c|c|c|c|c|c|}
\hline الدلالة & قيمة "ت" & المعياري & المتوسط & التكر ار & الجنس & البعد \\
\hline \multirow{2}{*}{0.193} & \multirow{2}{*}{1.30} & 0.554 & 4.01 & 118 & ذكر & \multirow{2}{*}{ لارجة الكلية الاختيار المهني } \\
\hline & & 0.555 & 4.1 & 122 & أنثى & \\
\hline
\end{tabular}

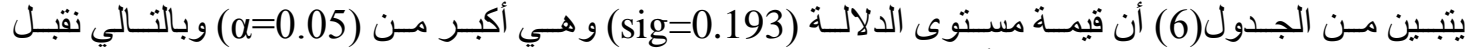

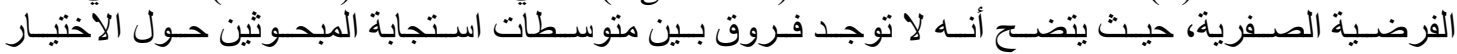
المهني تبعًا لمتغير الجنس.

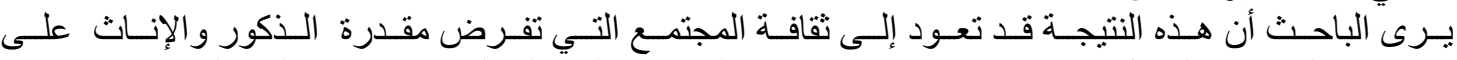

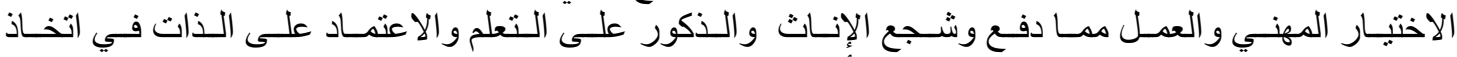

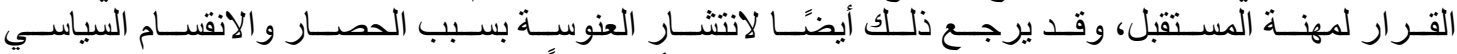

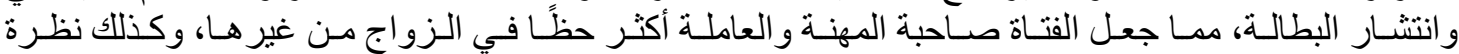

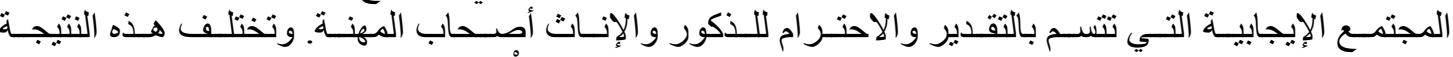

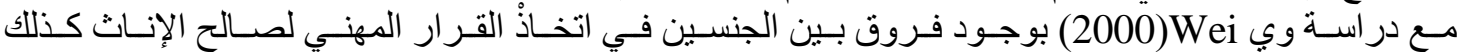

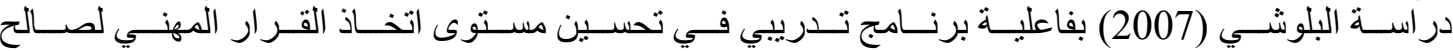

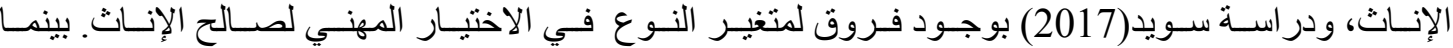

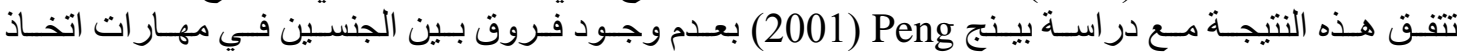

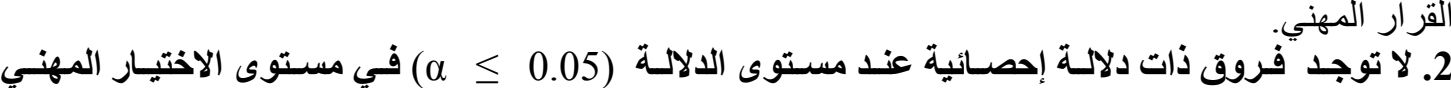
جدول (7) نتائج اختبار التباين الأحادي لمعرفة الفروق تبعًا لمتغير مستوى الاخل

\begin{tabular}{|c|c|c|c|c|c|c|}
\hline مستوى الدلالة & قيمة F & المربعات & الحرجاتة & المربعوع & مصدر التباين & المجالات \\
\hline \multirow{3}{*}{0.541} & \multirow{3}{*}{0.615} & 0.19 & 2 & 0.38 & بين المجمو عات & الدرجة الكلية \\
\hline & & \multirow{2}{*}{0.31} & 237 & 73.4 & داخل المجمو عات & \multirow[t]{2}{*}{ الاختبار المهني } \\
\hline & & & 239 & 73.7 & المجموع & \\
\hline
\end{tabular}

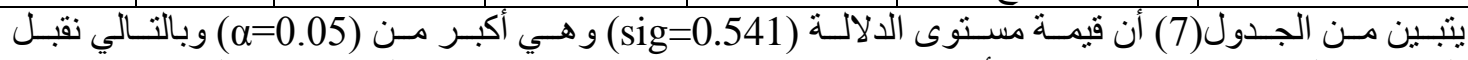

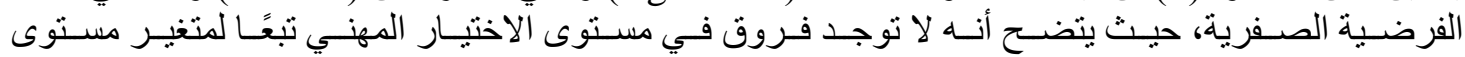

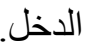

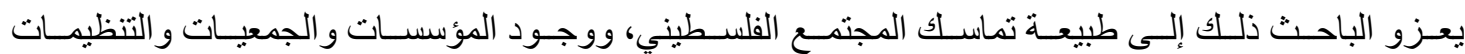

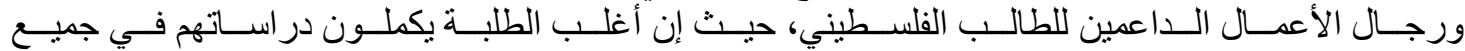

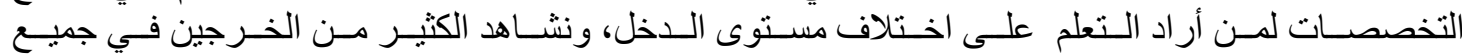

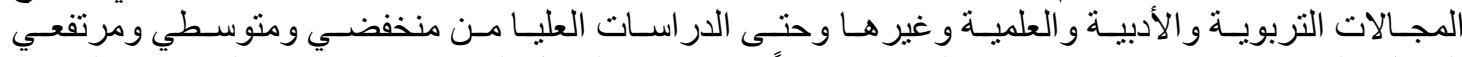

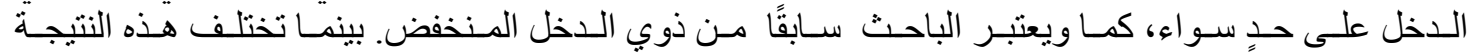

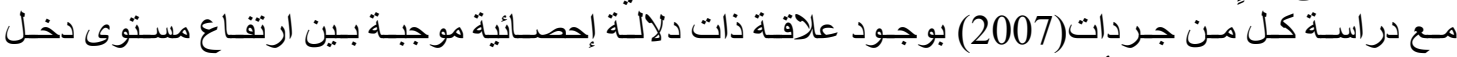

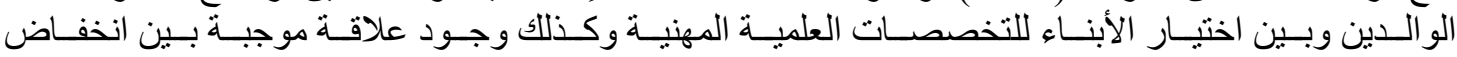

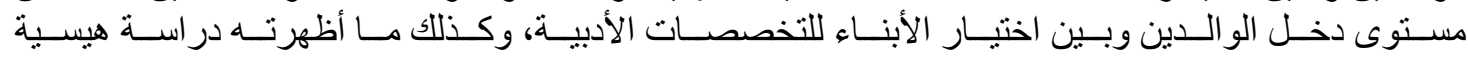

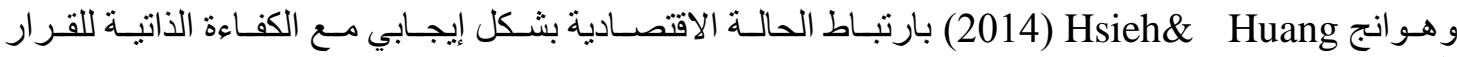

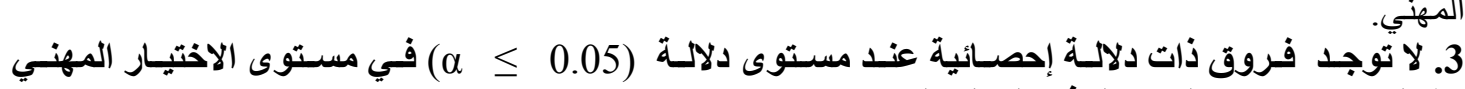
تبعًا لمتفير مستوى التحصيل في الصف التاسع. 


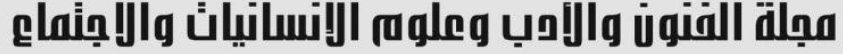

Journal of Arts, Literature, Humanities and Social Sciences www.jalhss.com

Volume (75) January 2022

العدد ( 2022 يناير

جدول (8 ) نتائج اختبار التباين الأحادي لمعرفة الفروق تبعًا لمتغير مستوى التحصيل في الصف التاسع

\begin{tabular}{|c|c|c|c|c|c|c|}
\hline مستوي & قيمة F & المربعات & الرجرية & المربعوع & مصدر التباين & المجالات \\
\hline \multirow{3}{*}{0.002} & \multirow{3}{*}{5.006} & 1.471 & 3 & 4.41 & بين المجمو عات & الدرجة الكلية \\
\hline & & \multirow{2}{*}{0.294} & 236 & 69.3 & داخل المجمو عات & \multirow[t]{2}{*}{ الاختبار المهني } \\
\hline & & & 239 & 73.7 & المجموع & \\
\hline
\end{tabular}

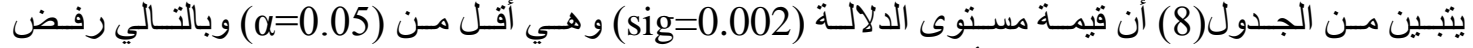

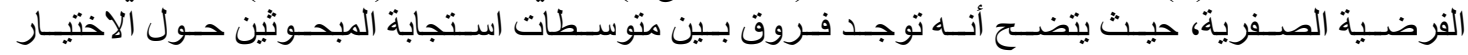

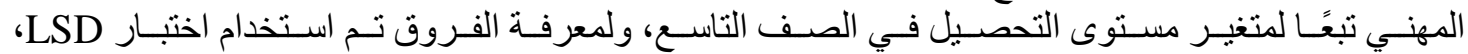

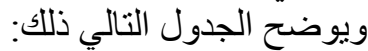

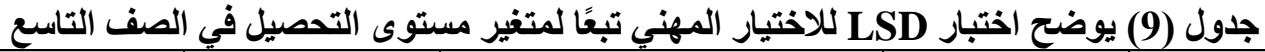

\begin{tabular}{|c|c|c|c|c|}
\hline مستوى الدلالة & الخطأ العياري & فروق المتوسطات (أبـب) & المنطقة ب & المنطقة أ \\
\hline .157 & .19909 & -.28261 & جيد & \multirow{3}{*}{ مقبول } \\
\hline .102 & .19242 & -.31603 & جيد جدًا & \\
\hline .005 & .18721 & $-.52566-{ }^{*}$ & ممتاز & \\
\hline .157 & .19909 & .28261 & مقبول & \multirow{3}{*}{ جيد } \\
\hline .754 & .10667 & -.03342 & جيد جدًا & \\
\hline .013 & .09697 & $-.24305-{ }^{*}$ & ميتاز & \\
\hline .102 & .19242 & .31603 & مقبول & \multirow{3}{*}{ جيد جدًا } \\
\hline .754 & .10667 & .03342 & جيد & \\
\hline .012 & .08242 & -20963- & مدتاز & \\
\hline .005 & .18721 & $.52566^{*}$ & مقبول & \multirow{3}{*}{ متاز } \\
\hline .013 & .09697 & $.24305^{\star}$ & جيد & \\
\hline .012 & .08242 & $.20963^{*}$ & جيد جدًا & \\
\hline
\end{tabular}

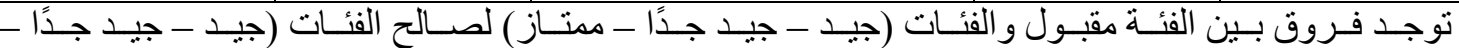

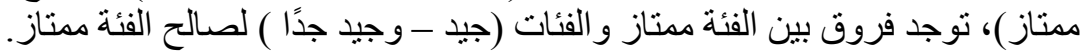

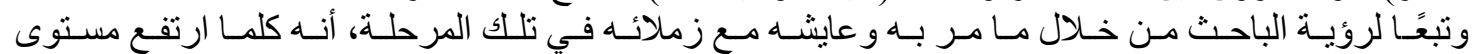

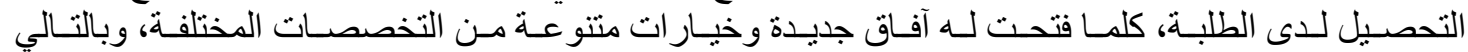

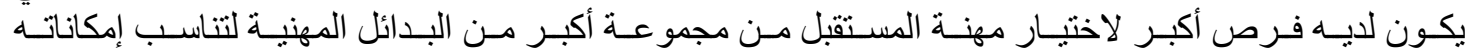

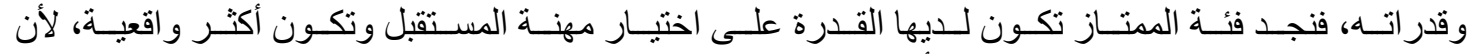

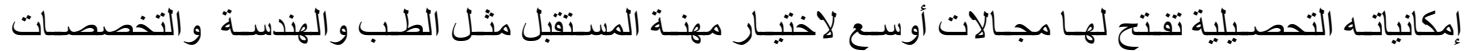

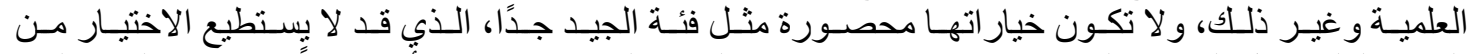

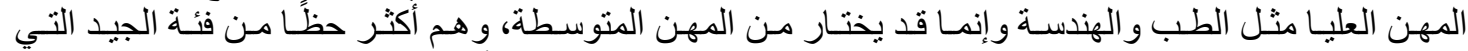

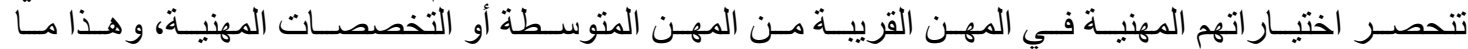

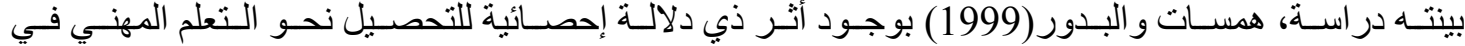

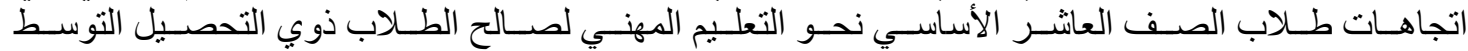
و المتدني مقابل ذوي التحصيل المرتفع.

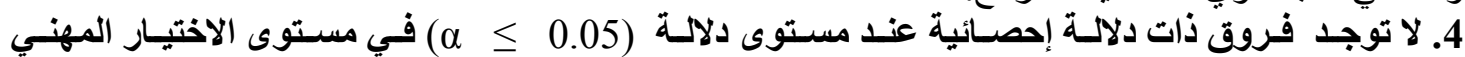
تبعًا لمتغير اختيار التخصص.

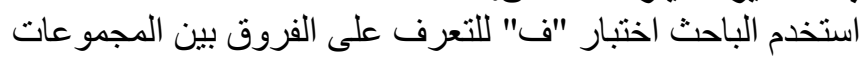




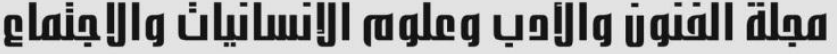

Journal of Arts, Literature, Humanities and Social Sciences www.jalhss.com

Volume (75) January 2022

العدد ( 75) يناير 2022

جدل (10) نتائج اختبار التباين الأحادي لمعرفة الفروق تبعًا لمتغير اختيار التخصص متص

\begin{tabular}{|c|c|c|c|c|c|c|}
\hline مستوى الدلالة & قيمة F & متوسط المربعات & الحرية & المربعات & مصدر التباين & المجالات \\
\hline \multirow{3}{*}{0.041} & \multirow{3}{*}{2.796} & 0.844 & 3 & 2.531 & بين المجمو عات & \multirow{3}{*}{ الاختيار المهنة الكلية } \\
\hline & & \multirow{2}{*}{0.302} & 236 & 71.21 & داخل المجموعات & \\
\hline & & & 239 & 73.74 & المجموع & \\
\hline
\end{tabular}

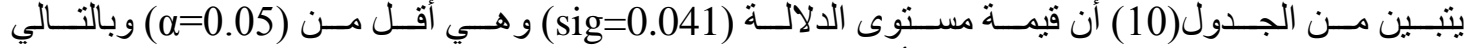

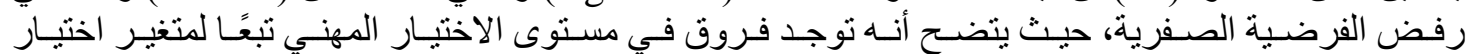

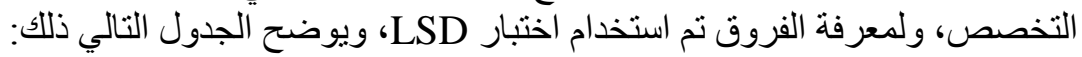

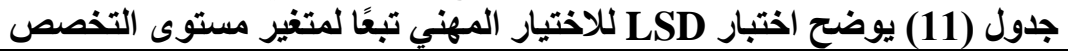

\begin{tabular}{|c|c|c|c|c|}
\hline مستوى الدلالة & الخطأ العباري & فروق المتوسطات (أبب) & المنطقة ب & المنطقة أ \\
\hline .008 & .07502 & $.19912^{*}$ & أدبي & \multirow{3}{*}{ علمي } \\
\hline .133 & .16088 & .24237 & مهني & \\
\hline .204 & .16678 & .21255 & شرعي & \\
\hline .008 & .07502 & $-.19912-$ & علمي & \multirow{3}{*}{ أدبي } \\
\hline .789 & .16177 & .04325 & مهني & \\
\hline .936 & .16764 & .01343 & شرعي & \\
\hline .133 & .16088 & -.24237 & علمي & \multirow{3}{*}{ مهني } \\
\hline .789 & .16177 & -.04325 & أدبي & \\
\hline .892 & .21990 & -.02982 & شرعي & \\
\hline .204 & .16678 & -.21255 & علمي & \multirow{3}{*}{ شرعي } \\
\hline .936 & .16764 & -.01343 & أدبي & \\
\hline .892 & .21990 & .02982 & مهني & \\
\hline
\end{tabular}

يوجد فروق بين الفئة علمي و الفئات (أدبي ومهني) لصالح الفئة علمي.

يرى الباحث أن وجود فروق بين منوسطات استجابة المبحوثين حول الاختيار المهني تبعًا لمتغير التخصص

لصالح الفئة علمي، نتيجة منطقية وذلك لأن التخصص التص العلمي يفتح مجالات أوسع أمام الطلبة للاختيار من

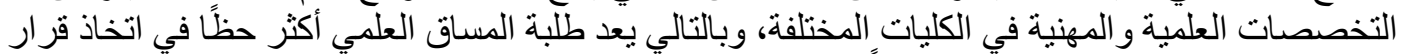

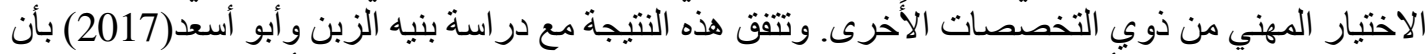

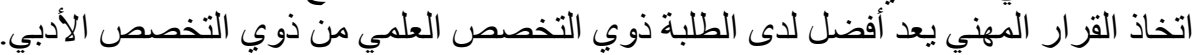

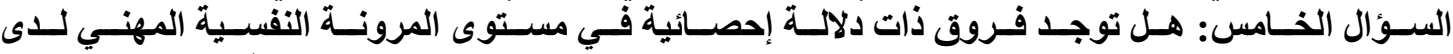

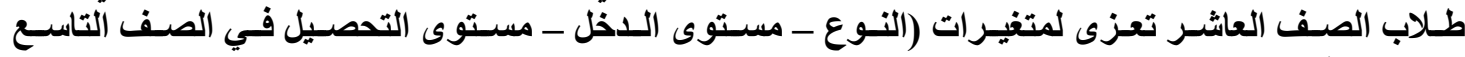

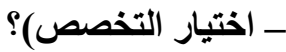

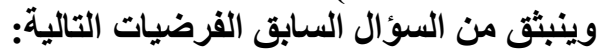

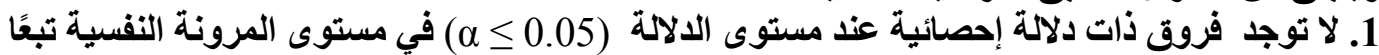
المتغير النوع. استخدم الباحث اختبار "ت" للتعرف على الفروق بين المجمو عنين

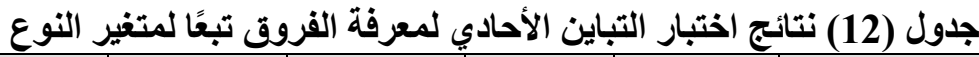

\begin{tabular}{|c|c|c|c|c|c|c|}
\hline الدلالة & قيمة "ت " & الالانحرياري & المتوسط & الت التكرار & الجنس & البعد \\
\hline \multirow{2}{*}{0.192} & \multirow{2}{*}{1.31} & 0.575 & 4.109 & 118 & ذكر & \multirow{2}{*}{ الدرجة الكلية المرونة النفسية } \\
\hline & & 0.519 & 4.202 & 122 & أنثى & \\
\hline
\end{tabular}




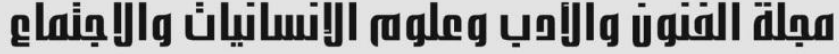

Journal of Arts, Literature, Humanities and Social Sciences www.jalhss.com

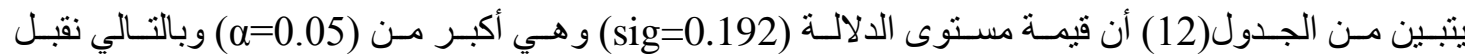

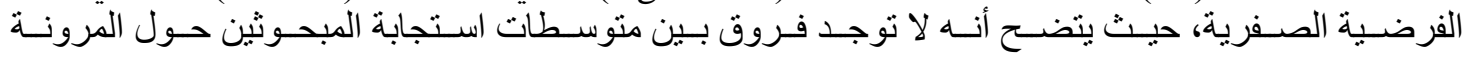

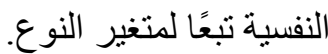

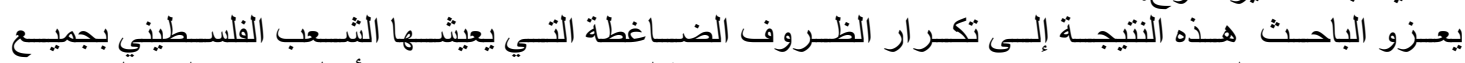

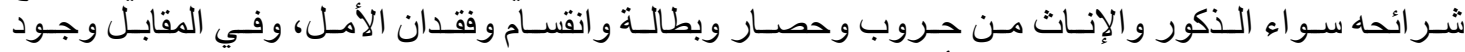

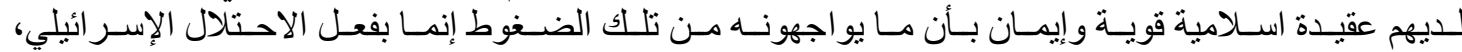

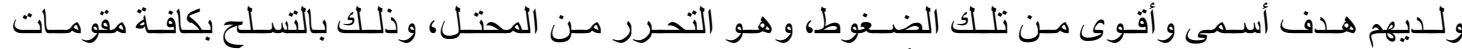

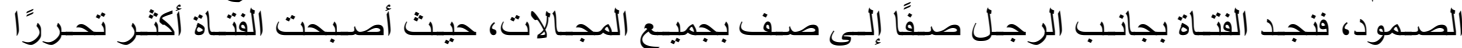

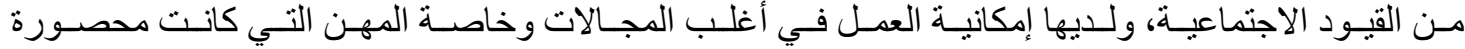

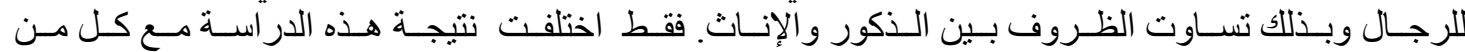

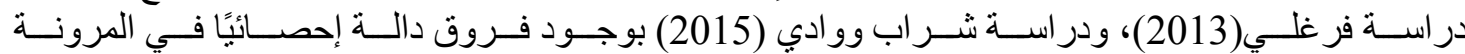

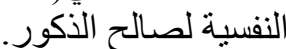

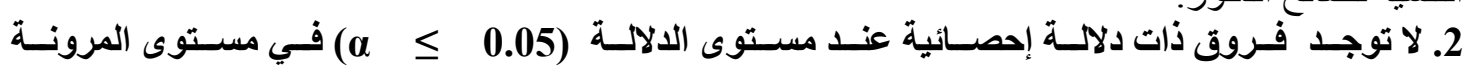
النفسية تبعًا لمتغير مستوى الاخدل.

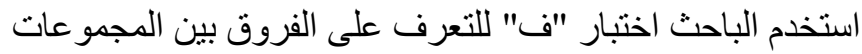

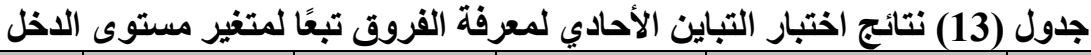

\begin{tabular}{|c|c|c|c|c|c|c|}
\hline الدلالة & قيمة F & المربعات & الرجرية & المربعات & مصدر التباين & المجالات \\
\hline \multirow{3}{*}{0.541} & \multirow{3}{*}{0.615} & 0.19 & 2 & 0.381 & بين المجمو عات & الدرجة الكلية \\
\hline & & \multirow{2}{*}{0.31} & 237 & 73.36 & داخل المجمو عات & \multirow[t]{2}{*}{ المرونة النفسية } \\
\hline & & & 239 & 73.74 & المجموع & \\
\hline
\end{tabular}

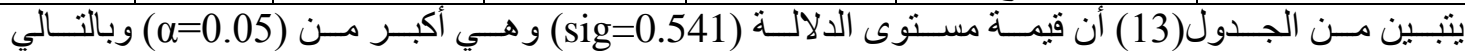

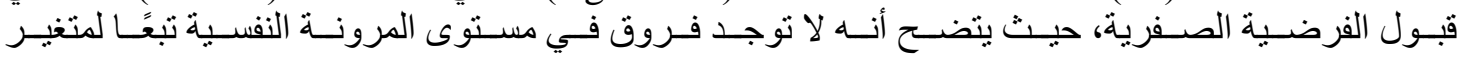
مستوى الدخل.

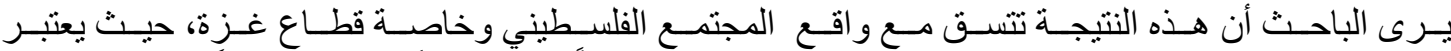

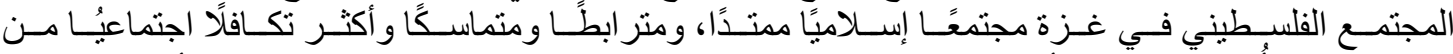

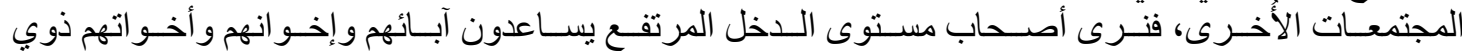

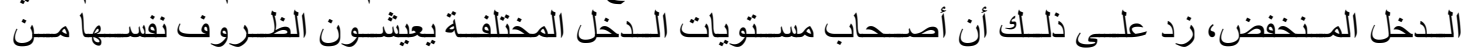

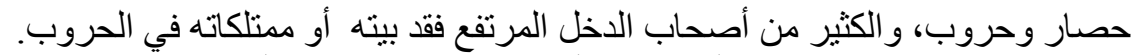

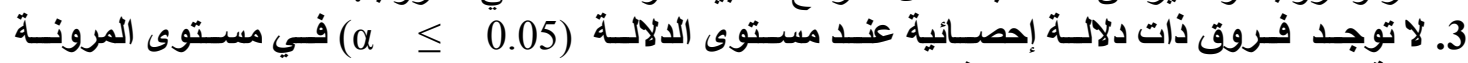

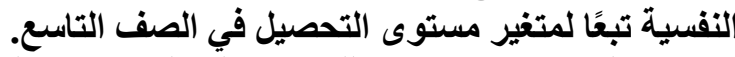

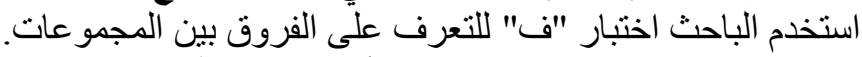
جدول (14) نتائج اختبار التباين الأحادي لمعرفة الفروق تبعًا لمتغير مستوى التحصيل في الصف التاسع

\begin{tabular}{|c|c|c|c|c|c|c|}
\hline مستوى & قيمة F & المربعات & الحرجية & المربعات & مصدر التباين & المجالات \\
\hline \multirow{3}{*}{0.002} & \multirow{3}{*}{5.006} & 1.471 & 3 & 4.412 & بين المجمو عات & الدرجة الكلية \\
\hline & & \multirow{2}{*}{0.294} & 236 & 69.33 & داخل المجمو عات & \multirow[t]{2}{*}{ المرونة النفسية } \\
\hline & & & 239 & 73.74 & المجموع & \\
\hline
\end{tabular}

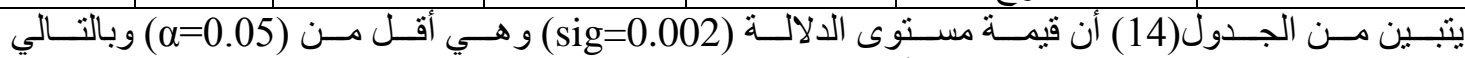

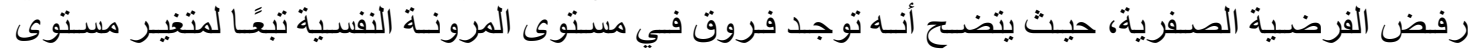

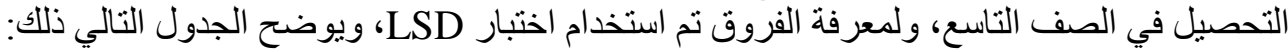




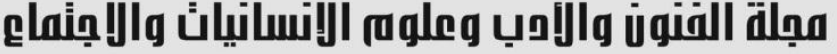

Journal of Arts, Literature, Humanities and Social Sciences www.jalhss.com

Volume (75) January 2022

العدد ( 75) يناير 2022

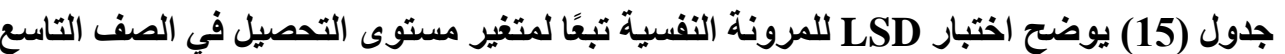

\begin{tabular}{|c|c|c|c|c|}
\hline مستوى الدلالة & الخطأ العياري & فروق المتوسطات (أـب) & المنطقة ب & المنطقة أ \\
\hline .157 & .19909 & -.28261 & جيد & \multirow{3}{*}{ مقبول } \\
\hline .102 & .19242 & -.31603 & جيد جدًا & \\
\hline .005 & .18721 & $-.52566-^{*}$ & متاز & \\
\hline .157 & .19909 & .28261 & مقبول & \multirow{3}{*}{ جيد } \\
\hline .754 & .10667 & -.03342 & جيد جدًا & \\
\hline .013 & .09697 & $-.24305^{*}$ & متناز & \\
\hline .102 & .19242 & .31603 & مقبول & \multirow{3}{*}{ جيد جدًا } \\
\hline .754 & .10667 & .03342 & جيد & \\
\hline .012 & .08242 & $-.20963-^{*}$ & ميتاز & \\
\hline .005 & .18721 & $.52566^{\star}$ & مقبول & \multirow{3}{*}{ 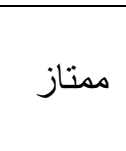 } \\
\hline .013 & .09697 & $.24305^{*}$ & جيد & \\
\hline .012 & .08242 & $.20963^{*}$ & جيد جدًا & \\
\hline
\end{tabular}

توجد فروق بين الفئة ممناز و الفئات (مقبول - جيد - جيد جدًا) لصالح الفئة ممناز.

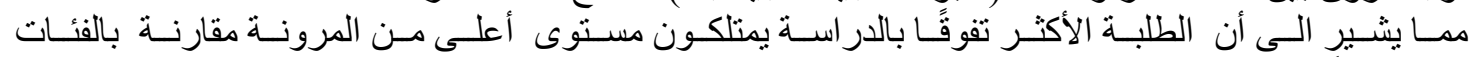

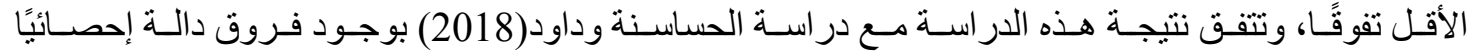
في المرونة النفسية تعزى للتحصيل الدراسي لصالح الطلبة ذوي التحصيل المرتفع.

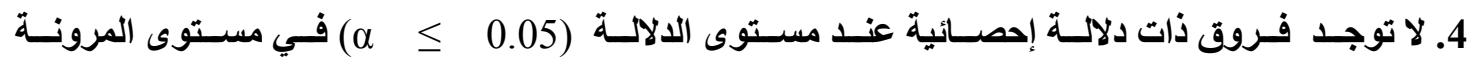
النفسية تبعًا لمتغير تبعًا لمتفير اختيار التخصص.

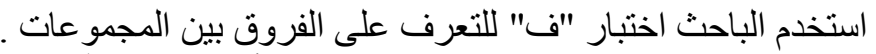

جدول (16) نتائج اختبار التباين الأحادي لمعرفة الفروق لبن تبعًا لمتغير اختيار التخصص

\begin{tabular}{|c|c|c|c|c|c|c|}
\hline الدستلة & قيمة F & المربعات & الحرية & المربعات & مصدر التباين & المجالات \\
\hline \multirow{3}{*}{0.410} & \multirow{3}{*}{1.21} & 0.844 & 3 & 2.531 & بين المجمو عات & الدرجة الكلية \\
\hline & & \multirow{2}{*}{0.302} & 236 & 71.21 & داخل المجمو عات & \multirow[t]{2}{*}{ المرونة النفسية } \\
\hline & & & 239 & 73.74 & المجموع & \\
\hline
\end{tabular}

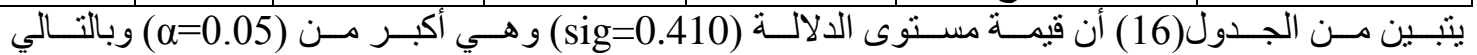

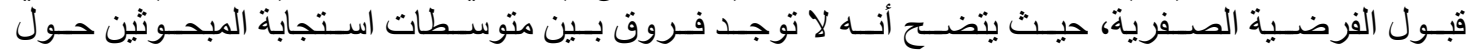

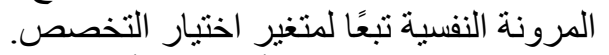

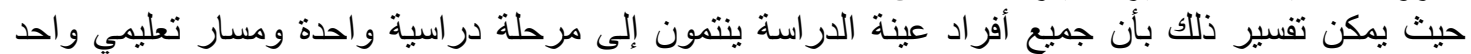

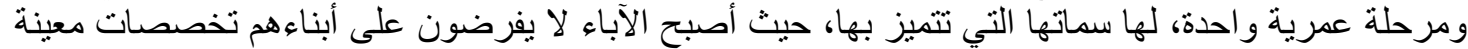

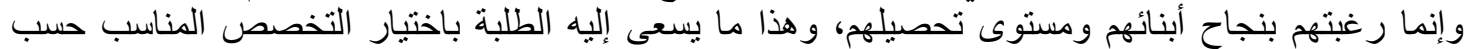

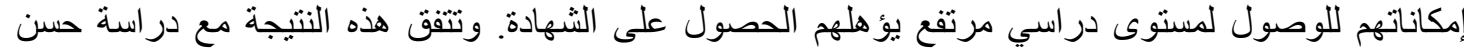

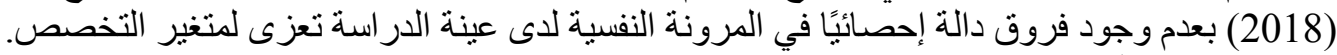
توصيات الاراسة :

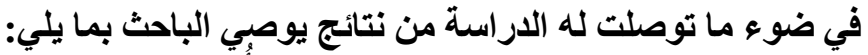

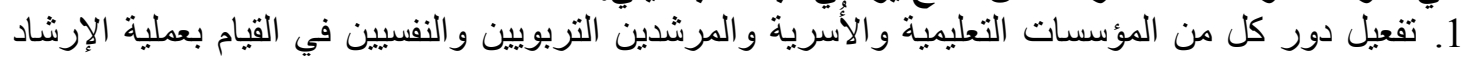

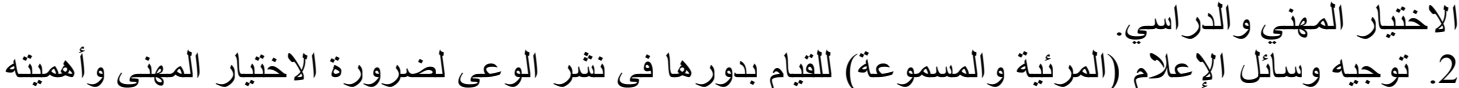
اختيار التخصصات الدر اسية. 


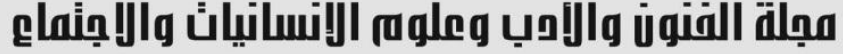

Journal of Arts, Literature, Humanities and Social Sciences www.jalhss.com

3. الاهتمام بالأنشطة اللاصفية في التوجيه والإرشاد المهني كالزيارات الميدانية للمهن المتوفرة للمساعدة على المئ اكتشاف ميول الطلبة المهنية وتنمية قدر اتهم. 4. تضمين المناهج الدر اسية موضوع الطية الاختيار المهني و أهميته بالمر احل الدر اسية بما يتناسب مع خصائص كل مرحلة عمرية. 5. إجر اء المزيد من الدراسات في مجال الاختيار المهني و الدر اسي لدى طلبة الصف العاثر. البحوث والدراسات المقترحة: المزئ 1. إجر اء در اسات لمعرفة العرات المقئة العة بين الاختيار المهني وبعض المتغيرات النفسية الاخرى مثل التوافق النفسي،

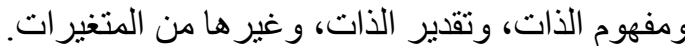

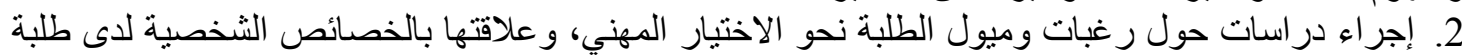
الصف العاشر. 3. در اسة مهار ات و أداء إدارة المدرسة و المعلمين والمرشدين النفسيين والتربوبين، و أثر ها على الاختيار المهني لاى طلبة الصف العاثر. 4. إنشاء بر امج إرشادية للاختيار المهني و الدر اسي ومعرفة أثز ها على طلبة الصف العاثر.

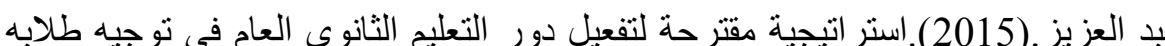
المراجع

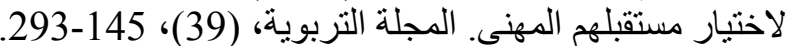

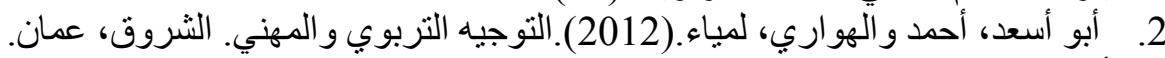
3. أبو القمصان، محمد.(2017).المساندة الاجتماعية و علاقتها بالمرونة النفسية لدى المع المطلقات في محافظات

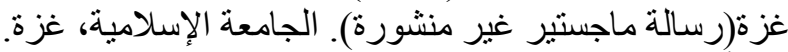

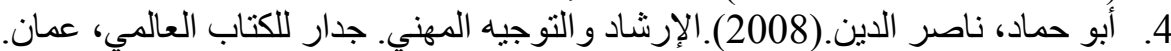

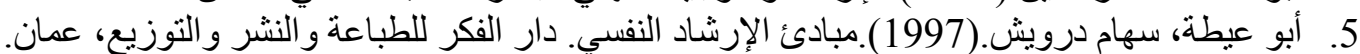

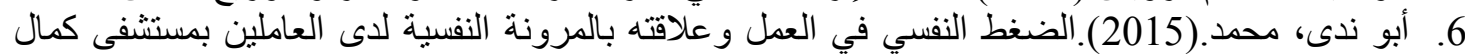

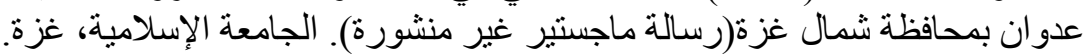

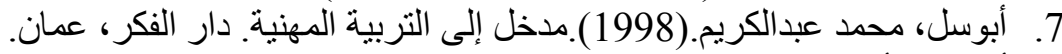

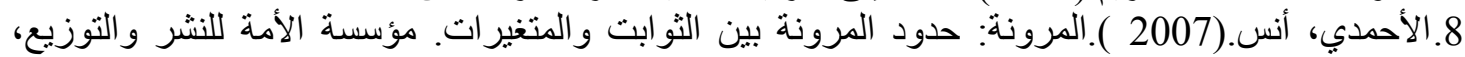
الرياض، المملكة العربية السعودية. 9. البلوشي، راشد بن غريب.(2007).بناء برنامج تدريبي مستند إلى أنموذج جيلات وقياس أثره في تحسين

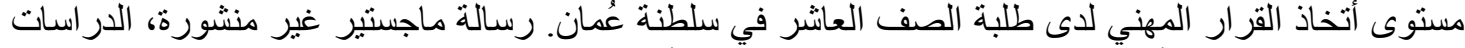

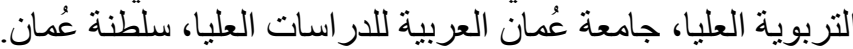

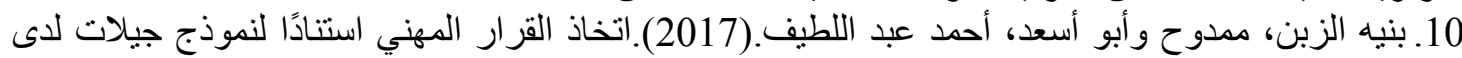

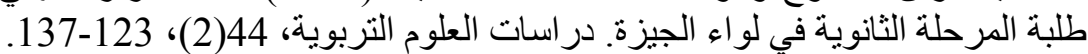

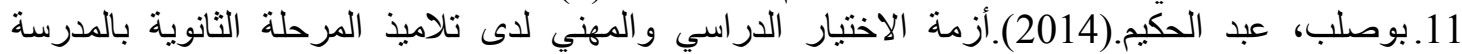

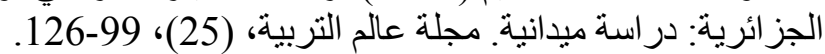

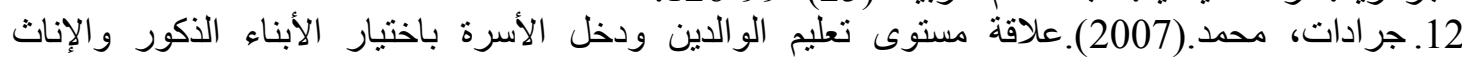

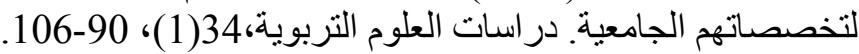

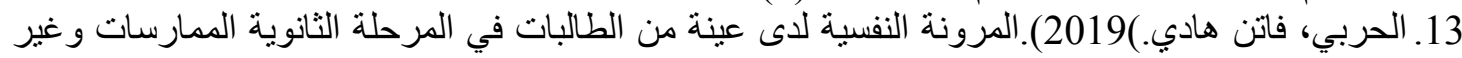

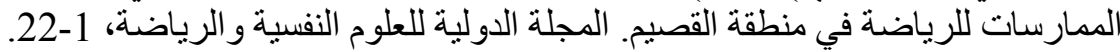
14. الحساسنة، وسام وداود، نسيمة.(2018).العنف المدرسي و علاقته بالمرونة النفسية لدى طلبة المرحلة الثانوية الثراية في المدارس التابعة لمديرية التربية والتعليم للواء وادي السير/ الأردن. المجلة التربوية الأردنية، 3(14)، 130-

15. 15سان، ولاء إسحق.(2009).فاعلية برنامج إرشادي مقترح لزيادة مرونة الأنا لدى طالبات الجامعة

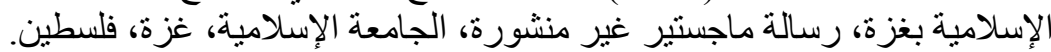




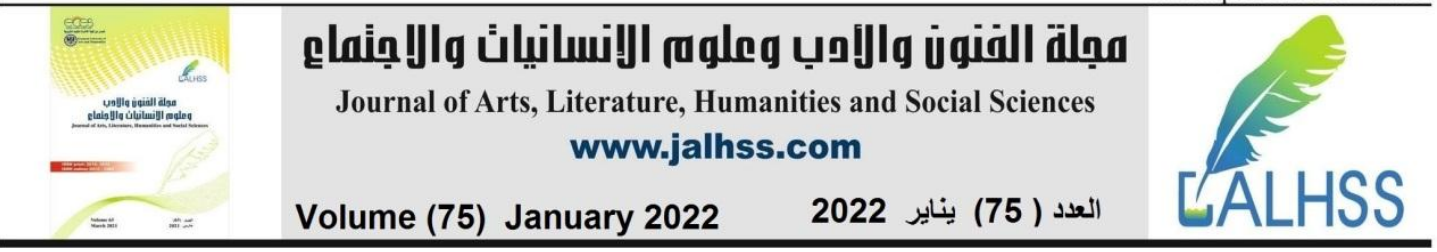

16.حسن، أماني(2018).القدرة التنبؤية للمرونة النفسية ومستوى الطموح بالمثابرة الأكاديمية لدى طالبات

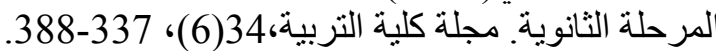

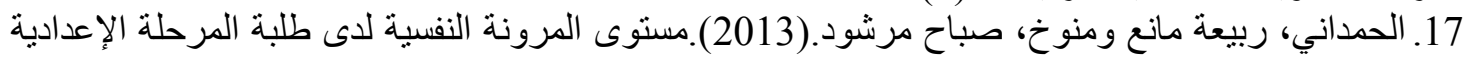

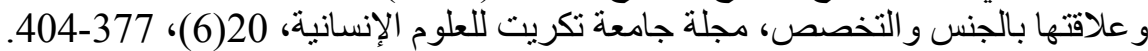

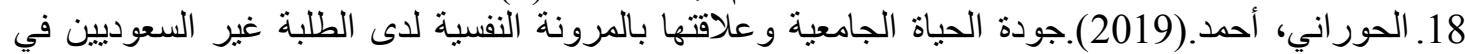

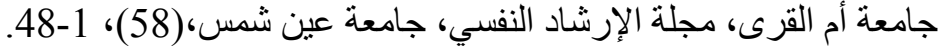

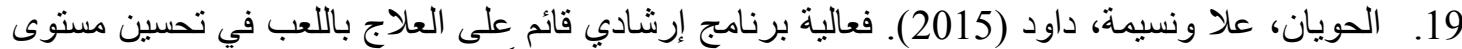
المهارات الاجتماعية والمرونة النفسية لاى الأطفال المساء إليهم جسدياً، دراسات الثادية العلوم التربوية، 42 (2)، $.421-405$

20. الختاتنة، سامي محسن.(2013).علم النفس الصناعي. دار الحامد للنشر و التوزيع، عمان.

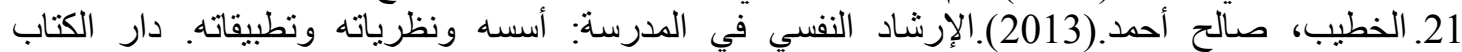
الجامعي، الإمار ات العربية المتحدة.

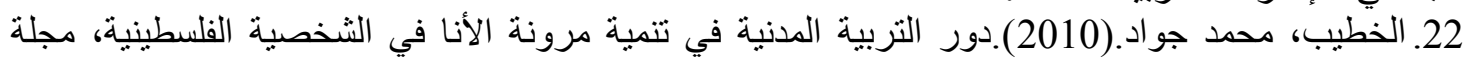
جامعة الأز هر بغزة، 12(23)، 2019، 2012-537.

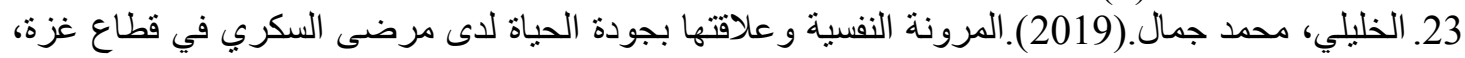
رسالة ماجستير غير منشورة، الجامعة الإسلامية، غزة)، فلسطين.

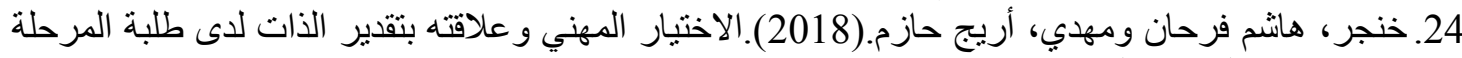

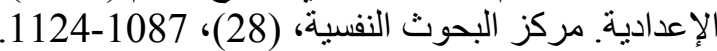
25. الداهري، صالح حسن.(2005).سيكولوجية الإنية التوجيه المهني ونظرياته. دار و وائل ،عمان.

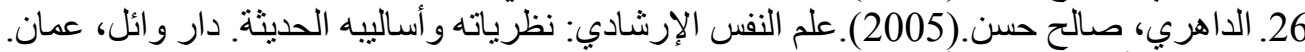

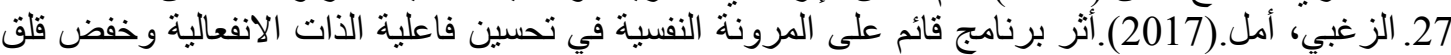
المستقبل المهني لطالبات الجامعة ذوات صعوبات التعلم الأكاديمي. مجلة البحث العلمي في التربية، (18)، 249-

28. زقاوة، أحمد عابد.(2016). دور التعليم العالي في تأهيل الطلاب لبناء مشروعهم المهني: دراسة ميدانية.

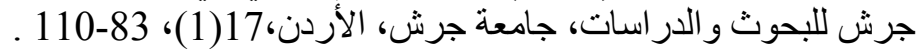

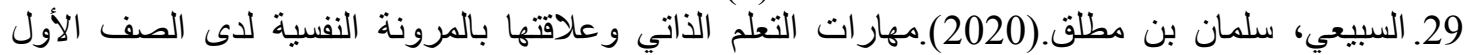

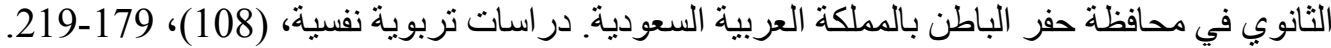
30. السعيدي، صالح سويت.(2017).أثر برنامج إرشادي جمعي في تحسين النمو المهني لدى طلبة النية المرحلة

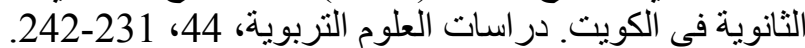

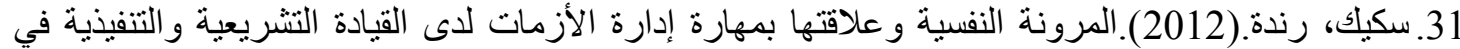

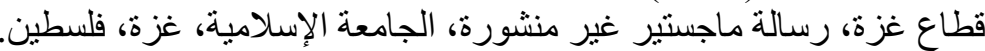

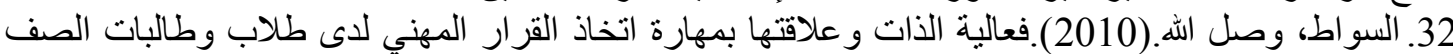

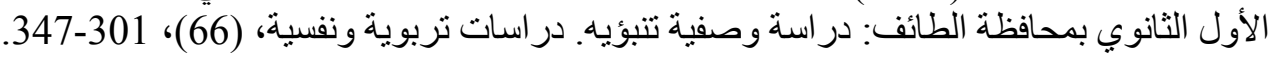

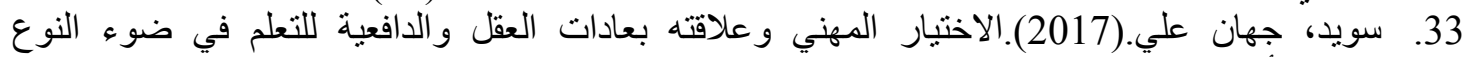

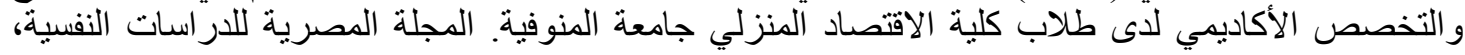
271-213، (97)27

34. شر اب، عبد الله ووادي، أكرم.(2015).المرونة النفسية ودافع الإنجاز الدراسي لدى طلبة المرئة المرحلة الثانوية

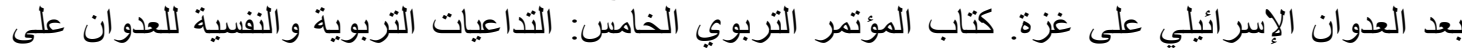

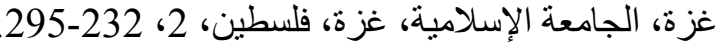

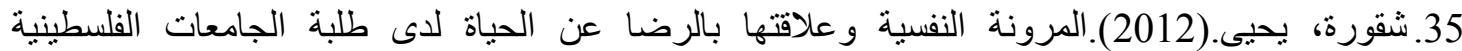
بمحافظات غزةة (رسالة ماجستير غير منشورة).

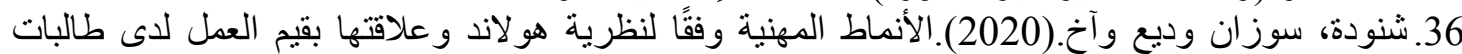

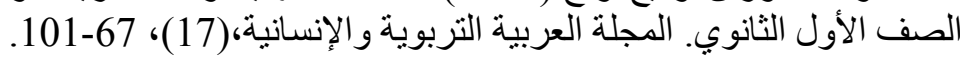




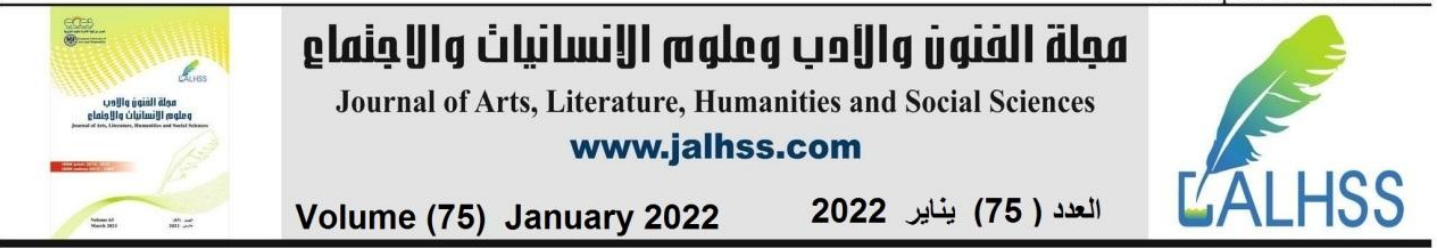

37. صباح، عبد الهادي وبركات، زياد.(2017).تقنين مقياس التفضيل المهني لهو لاند في البيئة الفلسطينية. المجلة

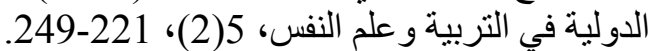

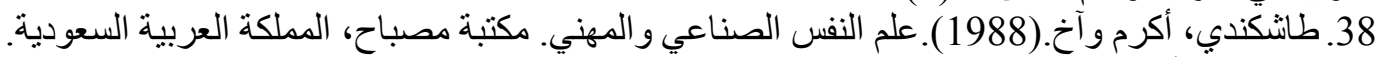

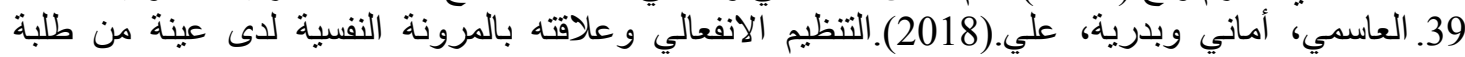

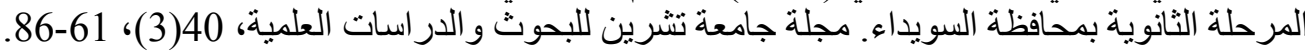

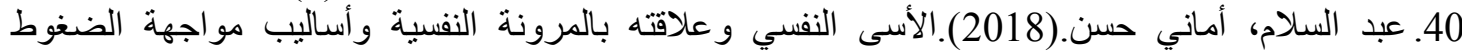

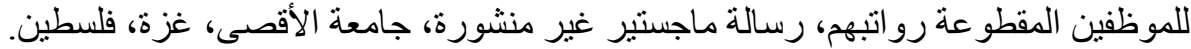

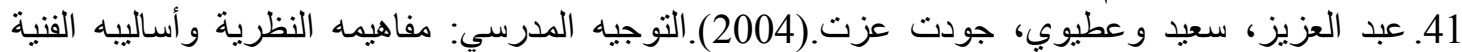

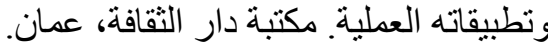

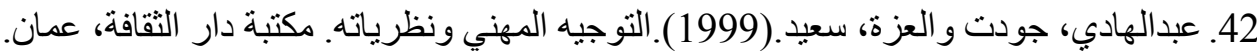

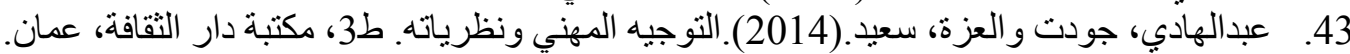

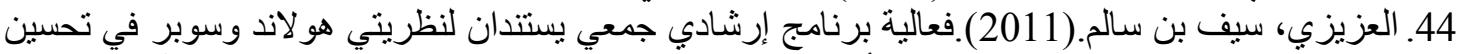

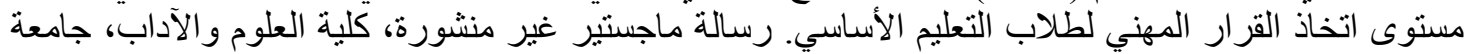
نزوى، سلطنة عُمان.

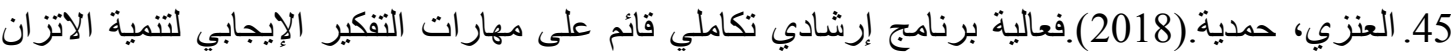

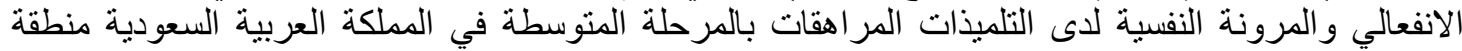

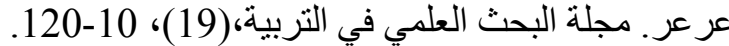

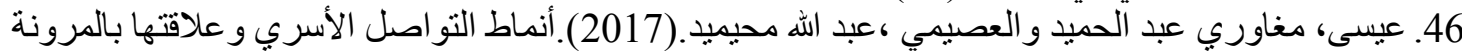

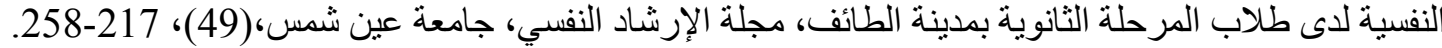

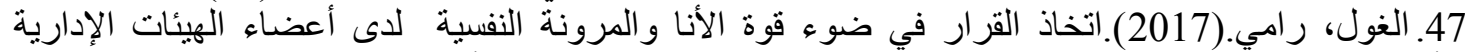

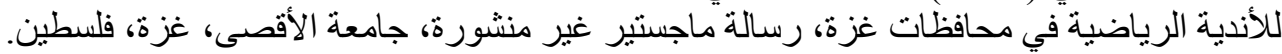

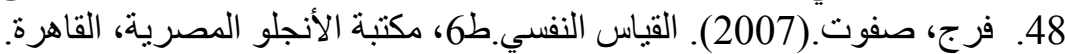

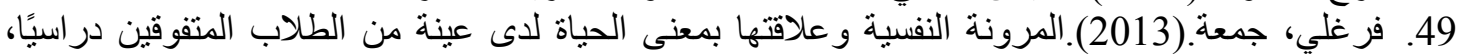
مجلة كلية التربية، جامعة طنطا، (51)، (51)، 127-1482.

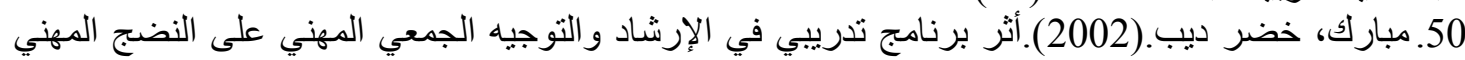

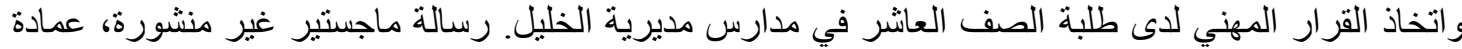
الدراسات العليا، جامعة القسن، فلسطين.

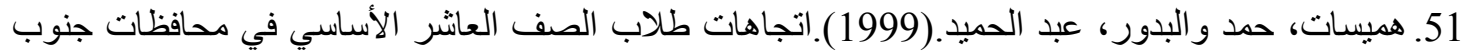

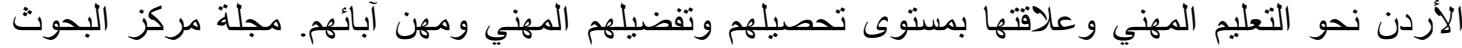

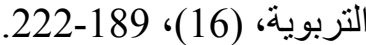
52. يونس، ياسمينا.(2018).الكفاءة الذاتية المدركة و علاقتها بالمرونة النفسية لدى عينة من طالبات معلمات

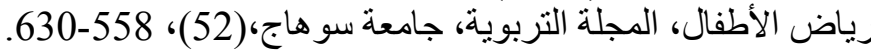

53. Adachi, T.(2001)An examination of the relationships among career decision making self-efficacy, vocational motives, and vocational indecision: a study of women's junior college students. Shinridaku kenkyu Japanese journal of psychology. 72 (1), 10-18.

54. Baltaci, H. C \& Karatas, Z.(215).perceived social support, depression and life satisfaction as the predictor of the resilience of secondary school students. Eurasian Journal of Educational Research,(60), 111-130.

55. Dowrick, c. Kokanovic R , hegarty K, Griffiths F, Gunn, J. (2008).Resilience and depression: perspectives from primary care. Health. 12(4):493-452.

56. Germeijs V. \& Versheuren, K.(2006)High school students choice. Journal of vocational behavior, 68 (2), 189-204. 


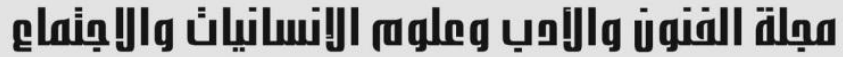 \\ Journal of Arts, Literature, Humanities and Social Sciences www.jalhss.com}

Volume (75) January 2022

57. Grace, fayombo.(2010).The relationship between personality traits and psychological resilience among the Caribbean adolescents. International Journal of Psychological Studies, 2(2).

58. Hsieh, Huang. J. T.(2014).The Effects Of Socioeconomic Status And Proactive Personality On Career Decision Self Efficacy. The National Career Development Association. The Career Development Quarterly. (62).

59. Johnson, p . Schamuhu, T . Nelson, D. Buboltz. W.(2014). Differentiation Levels of College Students: Effects on Vocational Identity and Career Decision Making. The National Development Association. The Career Development Association. The Career Devlopment Quarterly. (62).

60. Kapoor, B \& Tomar, a .(2016).Exploring connections between students psychological sense of school membership and skills, Indian journal of positive psychology, 7(1), 55-59.

61. Mota, c \& Matos, p .(2015). Adolescents in Institutional Care: Significant Adults, Resilience and Well-Being. Child Youth Care Forum, 44. 209-224.

62. Novotny. J \& Kremenkova, I.(2016).The relationship between resilience and academic performance at youth placed. Atrisk ceskoslovensk psychologie, 6, 553566.

63. Peng, H.(2001)Comparing The Effectiveness Of Two Different Career Education Courses On Career Decidedness For College Freshmen: An Exploratory. Study. Journal Of Career Development.28(1),29-41.

64. Shi, Meng \& et al.(2015).The mediating role of resilience in the relationship between stress and life. BMC Medical Education, 15(16), 1-7.

65. Speight, N.P.(2009).The relationship between self- efficacy, resilience and academic achievement among African. dissertation, Washington DC: Howard University.

66. Wei, c.(2000)Cultural differences in career decision making styles and selfefficacy. Journal of vocational behavior, 57 (3), 365-378. 